\title{
Microencapsulation of Probiotics for Gastrointestinal Delivery
}

\author{
Michael T. Cook ${ }^{\mathrm{a}, \mathrm{b}}$, George Tzortzis ${ }^{\mathrm{c}}$, Dimitris Charalampopoulos ${ }^{\mathrm{a} *}$, \\ Vitaliy V. Khutoryanskiy*
}

${ }^{a}$ Department of Food and Nutritional Sciences, University of Reading, Reading, RG6 6AD, United Kingdom

${ }^{b}$ Reading School of Pharmacy, University of Reading, Reading, RG6 6AD, United Kingdom

${ }^{c}$ Clasado Research Services Ltd, Science and Technology Centre, University of Reading, Earley Gate, Whiteknights Road, Reading, RG6 6BZ, UK

*Corresponding author at: Department of Food and Nutritional Sciences (D. Charalampopoulos) and Reading School of Pharmacy (V. Khutoryanskiy), University of Reading, Reading, RG6 6AD, United Kingdom

E-mail: D.Charalampopoulos@reading.ac.uk/V.Khutoryanskiy@reading.ac.uk

Tel: +44 (0) 1183788216 (D.Charalampopoulos)/ +44 (0) 1183786119 (V. Khutoryanskiy)

Keywords: Alginate, controlled release, encapsulation, enteric, lactobacillus, bifidobacterium.

\begin{abstract}
:
The administration of probiotic bacteria as nutraceuticals is an area that has rapidly expanded in recent years, with a global market worth $\$ 32.6$ billion predicted by 2014. Many of the health promoting claims attributed to these bacteria are dependent on the cells being both viable and sufficiently numerous in the intestinal tract. The oral administration of most bacteria results in a large loss of viability associated with passage through the stomach, which is attributed to the high acid and bile salt concentrations present. This loss of viability effectively lowers the efficacy of the administered supplement. The formulation of these probiotics into microcapsules is an emerging method to reduce cell death during GI passage, as well as an opportunity to control release of these cells across the intestinal tract. The majority of this technology is based on the immobilization of bacteria into a polymer matrix, which retains its structure in the stomach before degrading and dissolving in the intestine, unlike the diffusion based unloading of most controlled release devices for small molecules. This review shall provide an overview of progress in this field as well as draw attention to areas where studies have fallen short. This will be followed by a discussion of emerging trends in the field, highlighting key areas in which further research is necessary.
\end{abstract}




\section{Introduction:}

Probiotics are a group of bacteria described by the Food and Agriculture Association of the United Nations (FAO) and World Health Organisation (WHO) as 'live microorganisms which when administered in adequate amounts confer a health benefit on the host'. The most common commercial bacteria are of the genera Bifidobacterium or Lactobacillus [1]. These bacteria are typically saccharolytic (capable of metabolizing sugars), gram-positive, rod shaped and reside in the large bowel [2]. The human gut, specifically the large bowel or colon, has a complex bacterial composition consisting of more than 50 genera of bacteria [3]; these can be either harmful (e.g. producing toxins), beneficial (e.g. synthesising vitamins) or both (for example microbes of the family Streptococcus)[4]. The rationale behind probiotics is that the supplementation of beneficial microorganisms can alter the microbial balance to aid the host, mirroring the aforementioned definition. Probiotics are reported to have a variety of health benefits when present in the human small and large intestine, although not all health claims are sufficiently supported by the literature. The mechanisms by which these probiotic bacteria are believed to provide positive health responses have been grouped into three areas: production of nutrients and cofactors, competition with pathogens for binding sites, and stimulation of host immune response[5]. Potential areas of benefit include the treatment of inflammatory bowel disease [6], irritable bowel syndrome [7], Helicobacter pylori infections and antibiotic-associated diarrhoea [8]. A wide variety of health claims are made, some of which are better supported by clinical trials than others. For example, Rembacken et al [9] demonstrated that probiotic $E$. coli Nissle 1917 had an ability to maintain the remission of ulcerative colitis (a form of inflammatory bowel disease) comparable to mesalazine. Another study by Mimura et al [10] indicated that a probiotic mix of bifidobacteria, lactobacilli, streptococci and Escherichia coli maintained antibiotic induced remission in patients with pouchitis, an ileal pouch inflammation associated with the treatment of ulcerative colitis. A large trial by Kukkonen et al [11] showed that a probiotic treatment at birth, which included galacto-oligosaccharides, which promote the growth of bifidobacteria, did not have the ability to reduce allergic diseases in young children, there was however, significant reduction in the incidences of eczema. This ability to reduce eczema in the young is demonstrated in another large study [12]. It should be noted that probiotic effects are often strain specific, so will not act as a 'cure-all'.

An important aspect of a probiotic is that during use it must remain viable, i.e. capable of being recultured on solid agar, in order to provide many of its health benefits [13], although there is a sizeable body of evidence showing that the components of dead cells may be able to exert some anti-inflammatory responses [14]. After the administration of a probiotic, there is, in many strains, a considerable loss of viability as they pass through the low $\mathrm{pH}$ of the stomach (Figure ) and high bile salt conditions of the intestine [15]. 


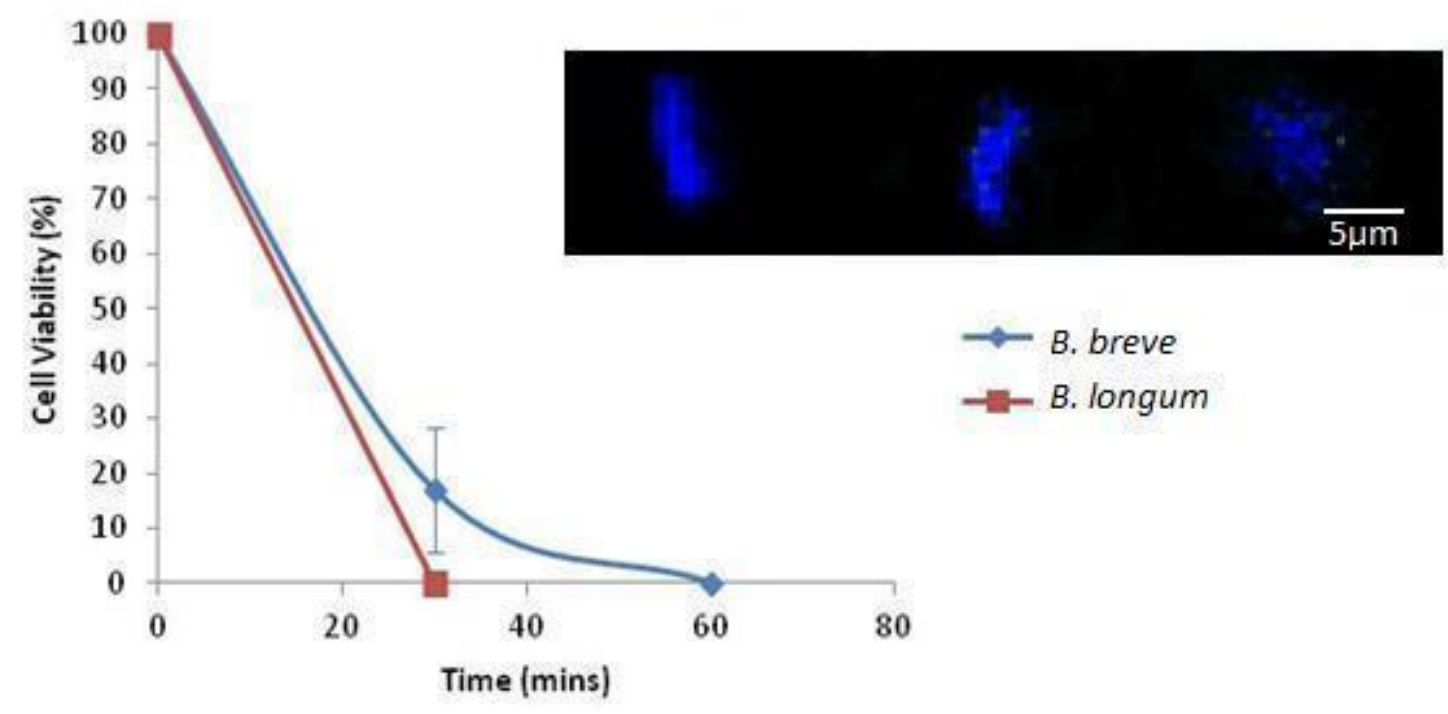

Figure 1: The viability of two strains of Bifidobacteria (Bifidobacterium longum and Bifidobacterium breve) in simulated gastric juice ( $2 \% \mathrm{NaCl}$ adjusted to $\mathrm{pH} 2$ with $1 \mathrm{M} \mathrm{HCl}$, data not published). Cell enumeration was performed by plate counts on Wilkins-Chalgren anaerobe agar. Insert:

Bifidobacterium breve encapsulated in alginate microcapsules during exposure to simulated gastric juice, showing stages of cell lysis (0, 30, 60 min from left to right, scale: 5 micron). Bifidobacterium breve was dyed with pHrodo succinimidyl ester and examined by confocal microscopy. Note the appearance of damage to the cell membrane and eventual breakdown of cell.

Such viability losses may be reduced by microencapsulating the bacteria in a polymer matrix. It is important that the microencapsulation matrix offers good protection from acid, and that the preparation routine be carried out in a way which is gentle enough not to damage the entrapped cells. In addition, the polymer used must be non-cytotoxic, as well as non-antimicrobial to ensure that the host, as well as the bacteria, are not harmed by it. The microencapsulation matrices used are typically covalently or ionically cross-linked polymer networks, or in some cases polymer granules which are not cross-linked, such as those produced during spray drying. There are even examples of probiotic-containing tablets reported to improve the viability during passage through the gastrointestinal (GI) tract [16]. Microencapsulation should also impart a degree of targeted release, by depositing the entrapped bacteria across the small and large intestine. The materials used for microencapsulation are typically naturally occurring polysaccharides and proteins as they often lack cytotoxicity, have safe biodegradation products and do not require the use of organic solvents for preparing the microcapsule.

This review intends to provide an insight into this emerging field from a pharmaceutical perspective, where current reviews provide information from within the world of food research [17-20]. Within this review, the characteristics of the gastrointestinal tract will first be considered, to provide an understanding of the challenges associated with the controlled delivery of probiotic bacteria. The current methods of encapsulation will then be discussed followed by an overview of the research completed to date. Some possible methodologies to study the efficiacy of microencapsulation systems for delivering viable probiotic cells to the intestine in vitro and in vivo will then be suggested. To close, some possible future trends in this field will be highlighted.

\section{Characteristics of the Gastrointestinal Tract}


When designing delivery systems for probiotic encapsulation with the aim of providing a controlled release it is necessary to consider the complex physiology of the GI tract (Figure). Typically the release of the bacteria will be triggered by degradation, disintegration or dissolution of the formulation as the bacteria are generally too large to diffuse from traditional delivery devices [21]. Along the $\mathrm{GI}$ tract there are various possible methods for delivery, based on: $\mathrm{pH}$, time, peristaltic pressures and bacterial fermentation.

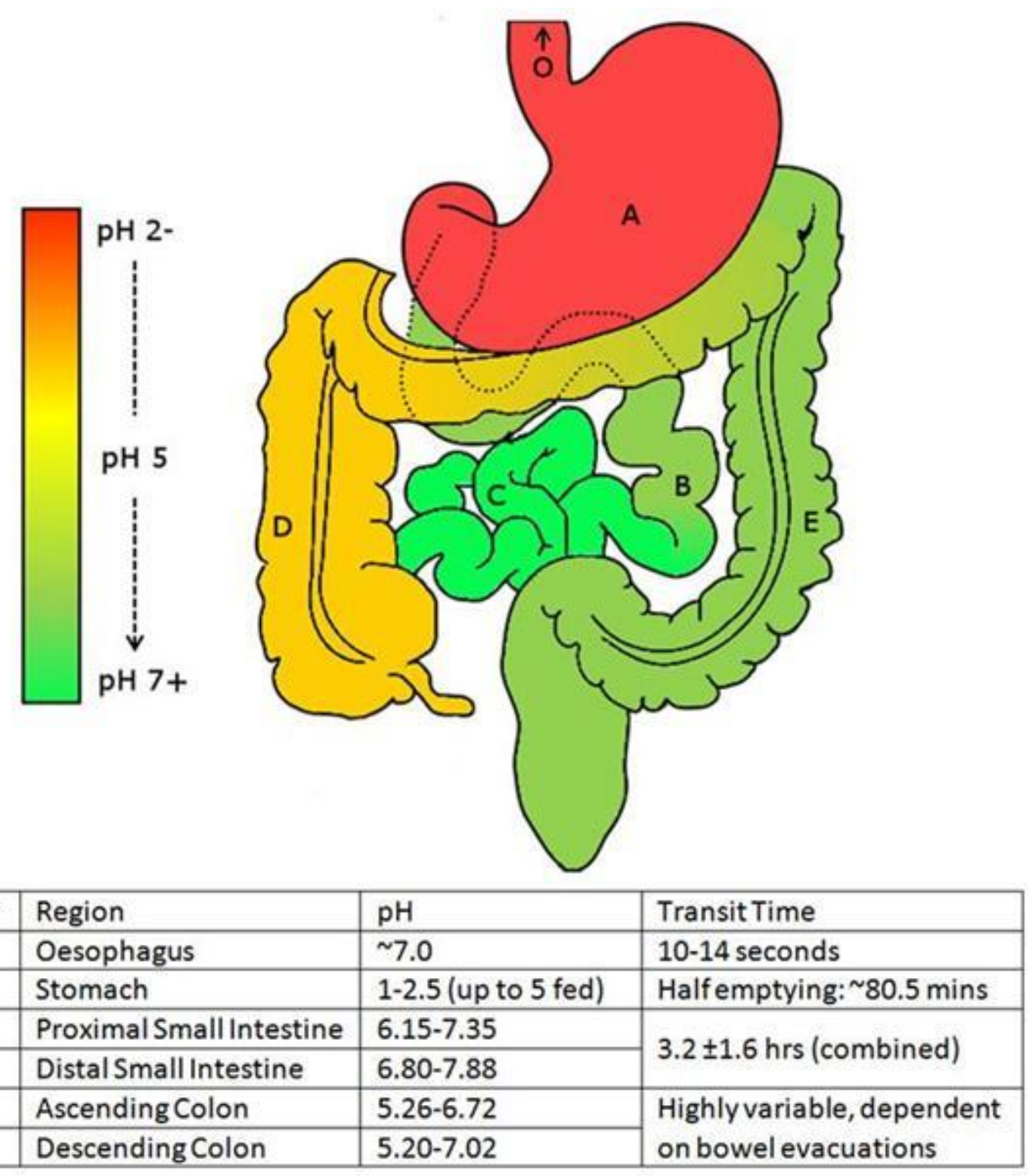

Figure 2: Characteristics of the GI tract, showing the $\mathrm{pH}$ at the different parts.

After ingestion, a microencapsulated probiotic will pass quickly through the oesophagus (taking around 10-14 seconds [22]) and reach the stomach; this is the point at which the greatest viability loss of bacteria is expected due to high levels of acid. The $\mathrm{pH}$ of, and transit time through, the stomach varies greatly between subjects and is dependent upon many factors, such as time since eating and age. The $\mathrm{pH}$ values of the stomach have been reported to lie within $\mathrm{pH} 1-2.5$ for uncontrolled groups [23] (with respect to feeding) but may be as high as $\mathrm{pH} 5$ for fed patients [24]. 
This provides a very large range so devices requiring very specific $\mathrm{pH}$ triggers may be ineffective in some patients. Gastric emptying time is also highly variable [25], and is often reported as between 5 minutes and two hours; however, the half gastric emptying time has been estimated using ${ }^{13} \mathrm{C}$ breath tests to be around 80.5 minutes [26]. The emptying of stomach contents is usually a result of peristaltic action known as the migrating myoelectric complex [27], whilst the pyloric sphincter ensures retention of large, insufficiently digested contents [22]. As a result, smaller particles will be retained for a shorter length of time. The stomach has a fluid capacity of up to approximately $1.5 \mathrm{~L}$ but usually contains only $50 \mathrm{~mL}$ in a fasted state [22]. In addition to acid, the stomach also contains pepsin, a proteolytic enzyme, which breaks down proteins. Pepsin is produced by the auto-catalytic cleavage of its precursor zymogen, pepsinogen, at the low $\mathrm{pH}$ of the stomach.

After passage through the stomach, the microcapsules will enter the small intestine, transit through which has been reported in one study to be $3.2 \pm 1.6 \mathrm{hrs}$ [28] and in another ranging from 0.5 to 9.5 hrs [29]. Significant variation in small intestinal transit time was observed upon repeated experimentation for a single patient [25], indicating a large variability within individual subjects. The $\mathrm{pH}$ of the small intestine has been estimated to lie in the range of $\mathrm{pH}$ 6.15-7.35 in the proximal region, rising to $\mathrm{pH} 6.80-7.88$ in the distal small intestine. After passage through the small intestine the capsules will reach the large intestine at which point the $\mathrm{pH}$ lowers slightly to $\mathrm{pH}$ 5.26-6.72 in the ascending colon, and pH 5.20-7.02 in the descending colon [30]. The transit time of pharmaceuticals in the large intestine is highly variable, with a range of 6-32 hrs typically reported [29], but longer times have also been noted [31]. As the capsules descend down the GI tract, the relative quantity of liquid present will decrease as the contents are compacted into faeces [25]. The large intestine, unlike the rest of the $\mathrm{GI}$ tract, is home to a large concentration of indigenous bacterial species, which themselves offer an opportunity for targeted delivery as some polysaccharides (such as pectin [32]) are biodegraded by the colonic microflora. This has been utilised as a mechanism of release for small drugs [33,34], but not as yet for the delivery of probiotics.

An additional tool for controlling release is mucoadhesion to the mucosal membranes lining the epithelial tissues [35]. The exact mechanism for mucoadhesion is not fully understood, but is believed to be based on the interpenetration of the mucoadhesive macromolecules and mucus, followed by the establishment of several types of interactions, including electrostatic, hydrogen bonding and hydrophobic interactions [36]. There are also possibly some diffusion effects and friction-like mechanical effects. This type of adhesion to mucosal surfaces will increase the time of residence in the GI tract and may be used in conjunction with delayed release formulations.

\section{Microencapsulation Methods}

The presence of such diverse conditions in the human digestive tract makes the designing of a probiotic release system challenging but also presents the possibility of producing a highly-tailored system that specifically targets the desired location. For the most part, such considerations are related to the material used to make the products (which are discussed further in the next section). However, the viability of a given product will also be dependent on whether the probiotic bacteria are able to survive the encapsulation process. The bacteria to be encapsulated will typically be micron sized and above, so nanotechnology is not an option. Despite being termed 'microcapsules' the current devices are typically between tens of microns [37] and millimetre size [38], and their ability to improve the survival of probiotics in many cases appears to be size dependent. The ideal microencapsulated probiotic product would either be a dry powder, with ease of storage and long shelf life or a wet gel with long term stability in a food product. 
The production of microcapsules containing probiotics falls into three main categories: extrusion, emulsion and spray drying (including spouted bed drying), with most of the research being carried out using the extrusion or emulsion technologies. The emulsion and extrusion processes generally refer to the cross-linking of the polymer solution after either suspension in oil or dropping into crosslinker respectively (explained in greater detail later). Extrusion based research is typically done using a syringe and needle, however spray systems have also been utilised, such as vibrating nozzles [39], air-atomizing nozzles [40] and spinning-disk atomization [41]. Despite this being a batch process, multi-nozzle arrays are often utilised by industry to scale up extrusion operations [42]. The use of these spray systems also reduces the size of microcapsules relative to needle extrusion, from millimetre size to a few hundred microns. The other popular microencapsulation method, using emulsions, has the benefit of producing very small ( $<100$ microns) microcapsules $[43,44]$. This is advantageous particularly to laboratory scale production, as specialist equipment is not necessary to produce these small particles.

Once the particles are prepared, it is usually desirable to isolate them as a dry powder for ease of handling and storage. To this end a number of drying procedures have been used including spray drying, air drying, freeze drying and fluid bed drying. Some production methods, such as spray drying and spouted bed drying directly produce a dried product, though these are less common and cause a large amount of cell damage and death. Oliveira et al encapsulated probiotic bacteria using complex coacervation to form microcapsules $[45,46]$ which was accompanied either by spray drying $[45]$ or by spouted bed drying [46]. Spouted bed drying is similar to spray drying but the fluid is passed into a large fluid-bed style drying drum, in which the particles produced are suspended and dried [47]. The spray drying of the bacteria produced microcapsules gave good protection to $B$. lactis and $L$. acidophilus in high acid conditions, with a loss of $2 \log \mathrm{cfu} / \mathrm{mL}$ associated with the drying procedure. The spouted bed drying, however, was not successful in protecting the microorganisms. This was put down to the damage caused to the bacteria by the spouted bed dryer, leading to a higher acid sensitivity. The advantages of these spray and spouted bed processes is that they are cheap and are already utilised by the pharmaceutical and biotechnological industry[48]. 
The drying of microcapsules could be an interesting area for further research, as most of the reported studies use wet microcapsules. Drying should reduce the microcapsule size [37] and improve its storage properties. In the research that has been carried out thus far there have been issues reported with the drying procedures [49], such as aggregation and the appearance of cracks during air-drying (Figure 3).

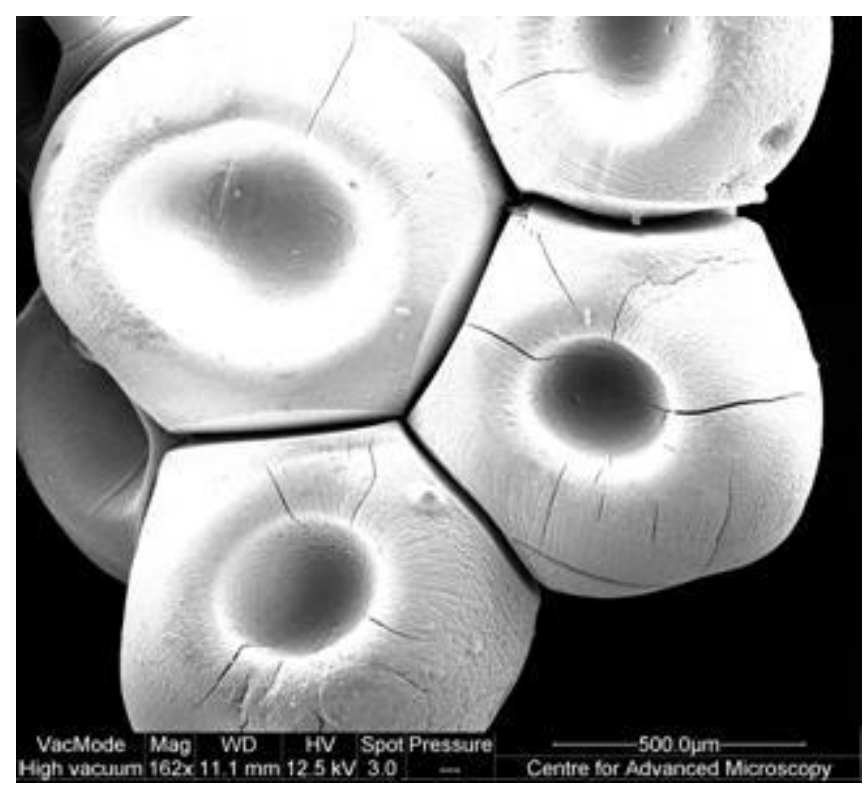

Figure 3: 'Clumping' of microcapsules observed during air-drying, caused by aggregation of particles during the drying process. Microcapsules were produced by extrusion of a $2 \%$ alginate solution into calcium chloride solution followed by hardening and drying for $24 \mathrm{hrs}$ at room temperature. Particles were then imaged by scanning electron microscopy (SEM). Reprinted with permission from Biomacromolecules 2011, 12, 2834-2840 [53]. Copyright (2011) American Chemical Society

Freeze drying is the drying of a frozen sample by the sublimation of ice under vacuum. Freeze drying has the benefit of being a process which bacteria can survive well with the addition of cryoprotectants [50,51]. However, the freeze drying is a time consuming process; in addition to this it does not reduce the particle size as greatly as other drying methods due to the retention of the hydrated structure. Fluid bed drying, on the other hand, achieves drying by the suspension of the load in air with additional heat to aid the evaporation of solvent. This process is advantageous as it is very quick, is commonly used in granulation and will separate out any granules in the dryer (Figure) [52]. 


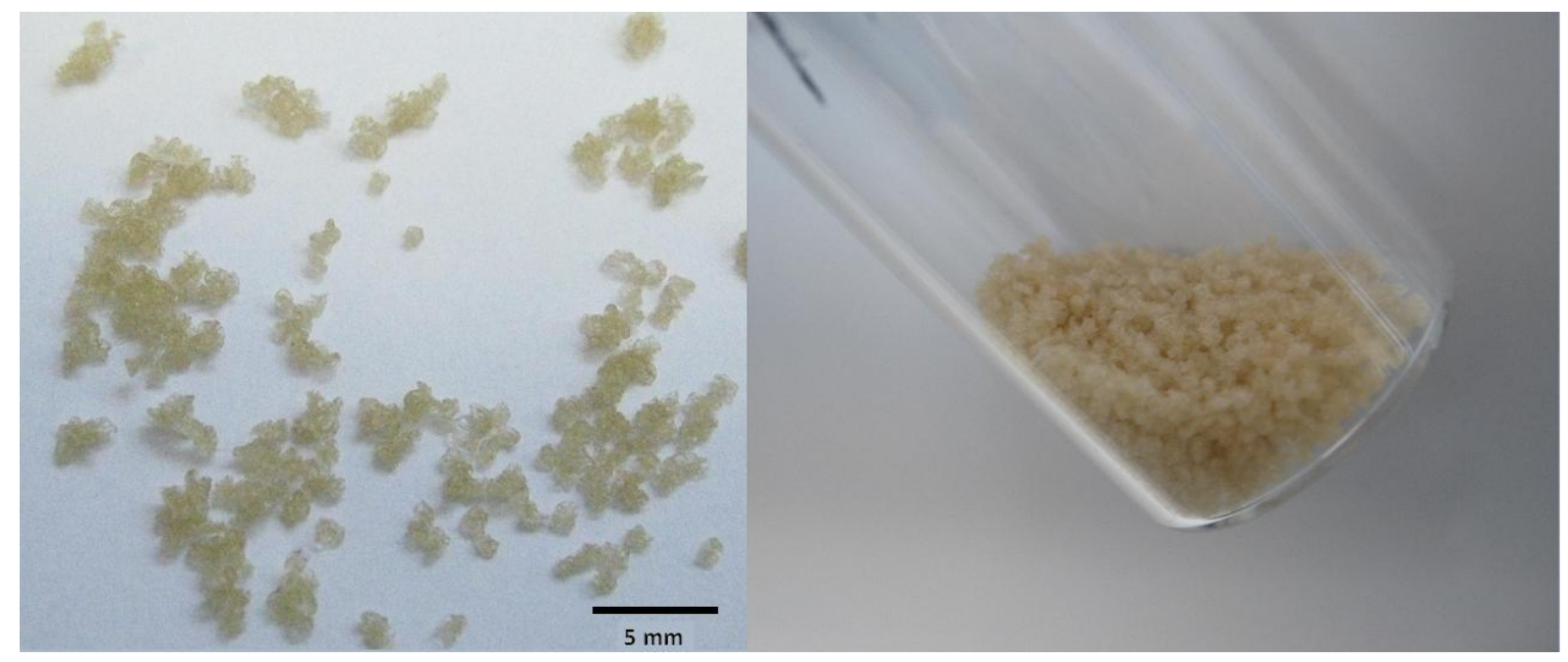

Figure 4: Fluid bed dried microcapsules, showing the granularity of the sample (left) and the large scale uniformity of the product (right). Microcapsules were produced as described in Figure 3, followed by drying using a fluid bed dryer (Retsch TG200, $15 \mathrm{~min}, 30^{\circ} \mathrm{C}$, air flow: $50 \%$ of full power, Idle flow: $183 \mathrm{~m}^{3} \mathrm{~h}^{-1}$ ).

It has also been shown that fluid bed drying does not detriment the ability of some microcapsules to protect encapsulated bacteria from low pHs [53]. One disadvantage to fluid bed drying is the aerobic environment necessary for drying, which could potentially harm strict anaerobes, though this has the potential to be overcome if a device could be engineered which circulated a non-oxygen containing atmosphere. There is also potential damage caused to bacteria by the heat used in the drying process $\left(80^{\circ} \mathrm{C}\right.$ and higher). Oven drying and vacuum oven drying are simpler techniques but have many disadvantages, such as the aforementioned clumping of particles [49] and slow drying times.

\section{Microencapsulation Materials}

\section{Encapsulation in Alginates}

In the literature to date, the most common encapsulation agent is alginate, a linear polysaccharide consisting of $1 \rightarrow 4$ linked $\beta$-(D)-guluronic (G) and $\alpha$-(L)-mannuronic $(M)$ acids derived from brown algae or bacterial sources (Figure)[54]. It is commercially available in a wide range of molecular weights from tens to hundreds of kilodaltons [55] and is particularly well suited to bacterial encapsulation due to its mild gelling conditions, GRAS (generally recognised as safe) status, and lack of toxicity [21]. Notably, due to the presence of carboxylic acid groups on both monomers, alginate carries a negative charge above its $\mathrm{pK}_{\mathrm{a}}$ (3.3-3.5). 

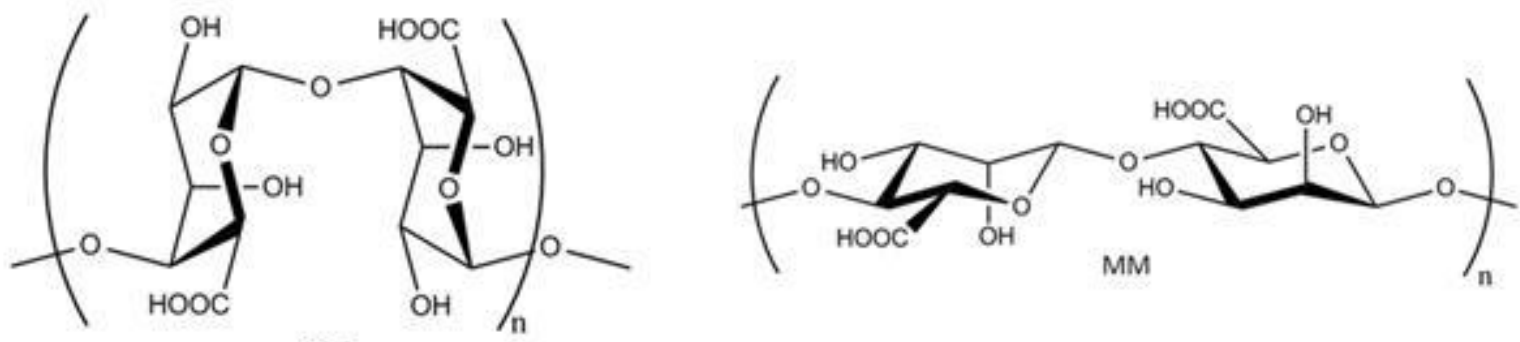

GG

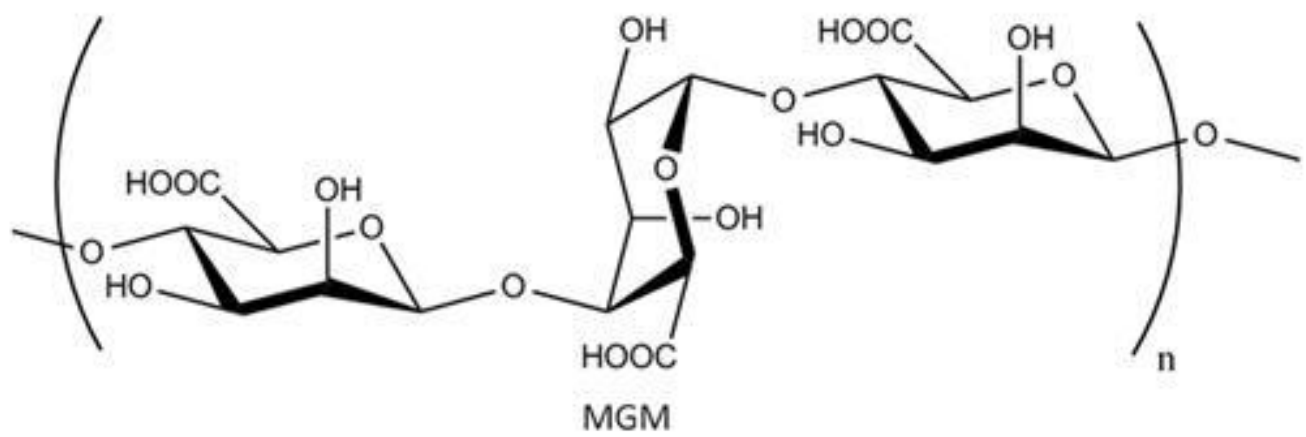

Figure 5: Structural intricacies of alginate

Alginate gels upon contact with divalent metals (e.g. calcium, cadmium or zinc [56]), forming what has been described as an "egg box structure" between four G residues (Figure 6) [57].

a
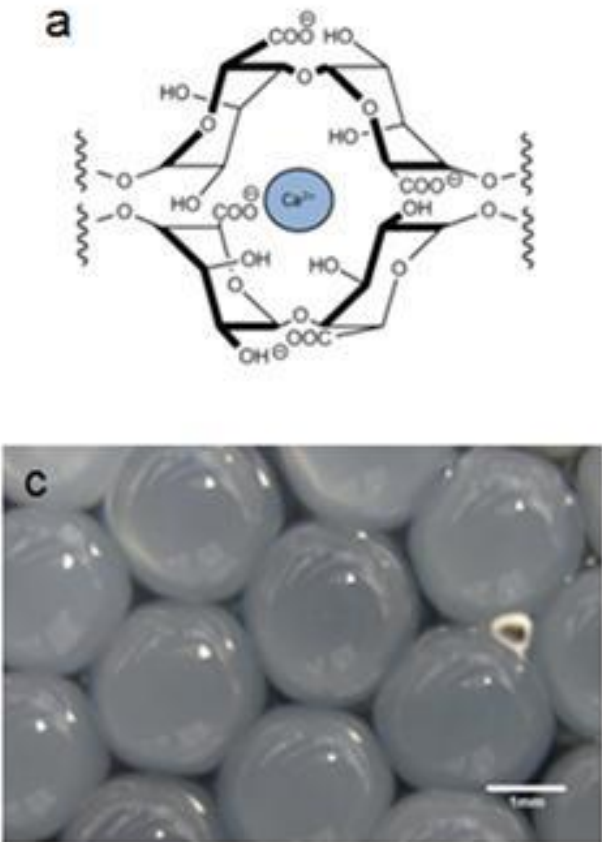

b

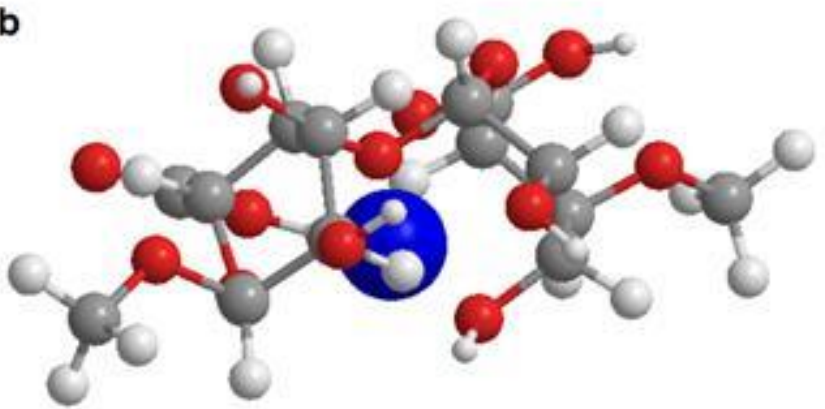

d

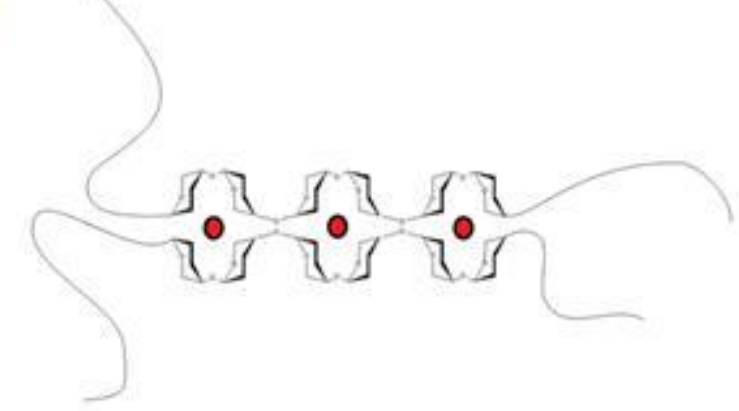


Figure 6: Egg-box style divalent metal binding in alginate (a), a GG dimer showing binding space (b), alginate microcapsules (c) and a schematic diagram showing chain association by egg-box binding (d).

This ability has been exploited to form microcapsules using an extrusion process (Figure). This involves the dropping of a concentrated alginate solution, most commonly through a needle, into calcium chloride solution, externally gelling the polymer into a microcapsule. The size of the microcapsules formed using external gelation is governed by the size of droplets formed during the extrusion process [39], with particles from as little as tens of microns being produced by spray technology [40], up to millimetre size when needle extrusion is used [58].

Another approach which is commonly used is the emulsion method (Figure) [59]. In this process the microcapsules are formed by the formation of a water-in-oil emulsion, usually stabilised by surfactants, such as Tween 80 , with the alginate being dissolved in the water phase. The alginate is usually then gelled by external gelation, i.e. the addition of calcium chloride solution to the emulsion. However, less commonly, the microcapsules may be formed by internal gelation [60], in which the alginate in solution contains calcium carbonate. An organic acid is added to this emulsion, and as it penetrates into the discrete water phase it reacts with the calcium carbonate forming calcium ions and carbonic acid, resulting in the gelation of the alginate.

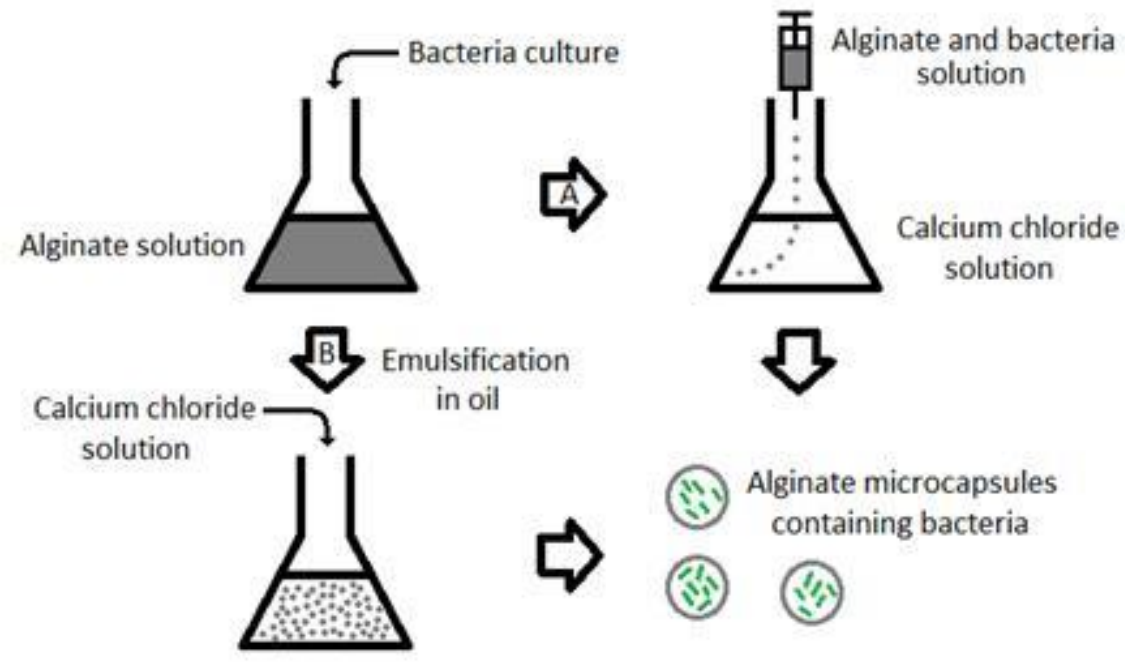

Figure 7: Bacterial encapsulation in alginate by A) extrusion and B) emulsion

The properties of alginate are well known and the encapsulation of both eukaryotic and prokaryotic cells within alginate gels has been researched [61-66]. Research thus far demonstrates the useful properties of alginate as an enteric delivery vehicle due to its acid- gel character at $\mathrm{pHs}$ below its $\mathrm{pK}_{\mathrm{a}}$ (3.3-3.5)[67], a result of the protonation of its acid groups. Microencapsulation with alginate alone has been evaluated as a possible method for improving the viability of probiotics during exposure to low $\mathrm{pH}$ and high salt conditions. Various studies have been carried out on a variety of probiotic bacteria using both the extrusion $[39,49,68,69]$ and the emulsion[16, 69-73] methods, with varied success. An overview of the available literature is shown in Table 1. Two studies [70, 71], have reported that encapsulation with alginate does not improve the cell viability upon exposure to low 
$\mathrm{pH}$ solutions, but does improve viability during storage in foods. However, one of these studies by Sultana et al [71] did not include data from unencapsulated bacteria, so interpretation of the results is difficult. The other study puts the low survival in gastric $\mathrm{pHs}(\mathrm{pH} 2-3)$ down to the particularly small ( $<100$ micrometer) sized microcapsules used [70]. This claim is supported by the findings of a study comparing the extrusion and emulsion methods [69], which showed that microcapsules produced by extrusion (typically capsules of $2-3 \mathrm{~mm}$ size) gave a greater protective effect than those produced by the emulsion method. Another study has shown greater survival of the bacteria in larger capsules produced by extrusion [39]. All other studies [16, 37, 39, 49, 53, 68, 69, 74] have reported improved survival of a wide host of lactobacilli and bifidobacteria as well as a probiotic yeast (Saccharomyces boulardii) in an acidic environment as a result of alginate encapsulation. It has also been shown that repeated 'coating' of alginate microcapsules with alginate improves viability in gastric conditions further[43, 75]. This system is possibly more like a size expansion of the existing microcapsules as the alginate coating sequesters the ions from within forming a gel externally, rather than a coating. The likely mechanism for the protection of cells by alginate encapsulation is a buffering effect [53] in which the activity of the protons is reduced by the dense polymer environment, but this has not been verified in the literature.

Table 1: Overview of some literature available on the alginate encapsulation of probiotics for GI delivery.

\begin{tabular}{|c|c|c|c|c|}
\hline $\begin{array}{l}\text { Encapsulation } \\
\text { material }\end{array}$ & State & Bacteria & Key Findings & Reference \\
\hline Alginate & Wet & $\begin{array}{l}\text { Lactobacillus } \\
\text { acidophilus }\end{array}$ & $\begin{array}{l}\text { Capsule size affects viability in } \\
\text { simulated gastric conditions }\end{array}$ & $\begin{array}{l}\text { Chandramouli } \\
\text { et al [39] }\end{array}$ \\
\hline $\begin{array}{l}\text { Alginate coated } \\
\text { with palm oil and } \\
\text { poly-L-lysine }\end{array}$ & $\begin{array}{l}\text { Freeze } \\
\text { Dried }\end{array}$ & $\begin{array}{l}8 \text { different } \\
\text { Lactobacilli and } \\
\text { Bifidobacteria }\end{array}$ & $\begin{array}{l}\text { Coating with palm oil and poly-L- } \\
\text { lysine improved viability in } \\
\text { simulated gastric conditions }\end{array}$ & Ding et al [37] \\
\hline $\begin{array}{l}\text { Alginate and } \\
\text { xanthan gum }\end{array}$ & $\begin{array}{l}\text { Freeze } \\
\text { Dried }\end{array}$ & $\begin{array}{l}\text { Lactobacillus } \\
\text { acidophilus }\end{array}$ & $\begin{array}{l}\text { Encapsulation improved cell } \\
\text { survival in simulated gastric juice } \\
\text { at as low as } \mathrm{pH} 1.2\end{array}$ & Kim et $a l[76]$ \\
\hline $\begin{array}{l}\text { Alginate coated } \\
\text { with either } \\
\text { chitosan, alginate } \\
\text { or poly-L-lysine- } \\
\text { alginate }\end{array}$ & Wet & $\begin{array}{l}\text { Lactobacillus } \\
\text { acidophilus, } \\
\text { Bifidobacterium } \\
\text { bifidum, } \\
\text { Lactobacillus casei }\end{array}$ & $\begin{array}{l}\text { Chitosan improved survival of } \\
\text { the bacteria best in simulated } \\
\text { gastric juice. }\end{array}$ & $\begin{array}{l}\text { Krasaekoopt et } \\
\text { al[77] }\end{array}$ \\
\hline Alginate & Wet & Lactobacillus casei & $\begin{array}{l}\text { Bacterial survival during } \\
\text { exposure to heat, bile salts and } \\
\text { low pH increases with alginate } \\
\text { concentration. }\end{array}$ & $\begin{array}{l}\text { Mandal et al } \\
{[16]}\end{array}$ \\
\hline Alginate and pectin & Wet & Lactobacillus casei & $\begin{array}{l}\text { Blending of pectin into } \\
\text { microcapsules improved cell } \\
\text { survival at low pH }\end{array}$ & $\begin{array}{l}\text { Sandoval- } \\
\text { Castilla et al } \\
{[58]}\end{array}$ \\
\hline
\end{tabular}




\begin{tabular}{|l|l|l|l|l|}
\hline $\begin{array}{l}\text { Alginate coated } \\
\text { with whey protein }\end{array}$ & $\begin{array}{l}\text { Freeze } \\
\text { Dried }\end{array}$ & $\begin{array}{l}\text { Lactobacillus } \\
\text { plantarum }\end{array}$ & $\begin{array}{l}\text { Alginate can be coated with } \\
\text { proteins; this greatly affects cell } \\
\text { survival at low pH. }\end{array}$ & Gbassi et al [78] \\
$\begin{array}{l}\text { Alginate coated } \\
\text { with chitosan, } \\
\text { sureteric } \\
\text { eze }{ }^{\circledR} \text { or acryl- }\end{array}$ & $\begin{array}{l}\text { Air } \\
\text { Dried }\end{array}$ & $\begin{array}{l}\text { Bifidobacterium } \\
\text { animalis }\end{array}$ & $\begin{array}{l}\text { Enteric polymers improved } \\
\text { survival at low pH. }\end{array}$ & $\begin{array}{l}\text { Liserre et al } \\
\text { [79] }\end{array}$ \\
$\begin{array}{l}\text { Alginate coated } \\
\text { with Chitosan }\end{array}$ & $\begin{array}{l}\text { Fluid }- \\
\text { Bed } \\
\text { Dried }\end{array}$ & $\begin{array}{l}\text { Bifidobacterium } \\
\text { breve }\end{array}$ & $\begin{array}{l}\text { Drying particles does not effect } \\
\text { their ability to protect bacteria } \\
\text { from low pH. Chitosan } \\
\text { penetration into alginate is very } \\
\text { slow. }\end{array}$ & Cook et al [53] \\
\hline
\end{tabular}

The coating, or incorporation, of other materials into the alginate microcapsules is a popular direction for probiotic microencapsulation research. Along with the protection that such coatings can offer to the microorganisms, other beneficial properties may also be imparted, such as giving greater control over bacterial release. The most popular coating material is the polysaccharide chitosan. Chitosan (Figure 8) is a natural, linear cationic polysaccharide containing both glucosamine and $\mathrm{N}$-acetyl glucosamine residues [80]. Chitosan is the (usually partially) $\mathrm{N}$-deacetylated form of chitin, a natural mucopolysaccharide derived from some natural supporting structures, such as the exoskeletons of crustaceans [81].

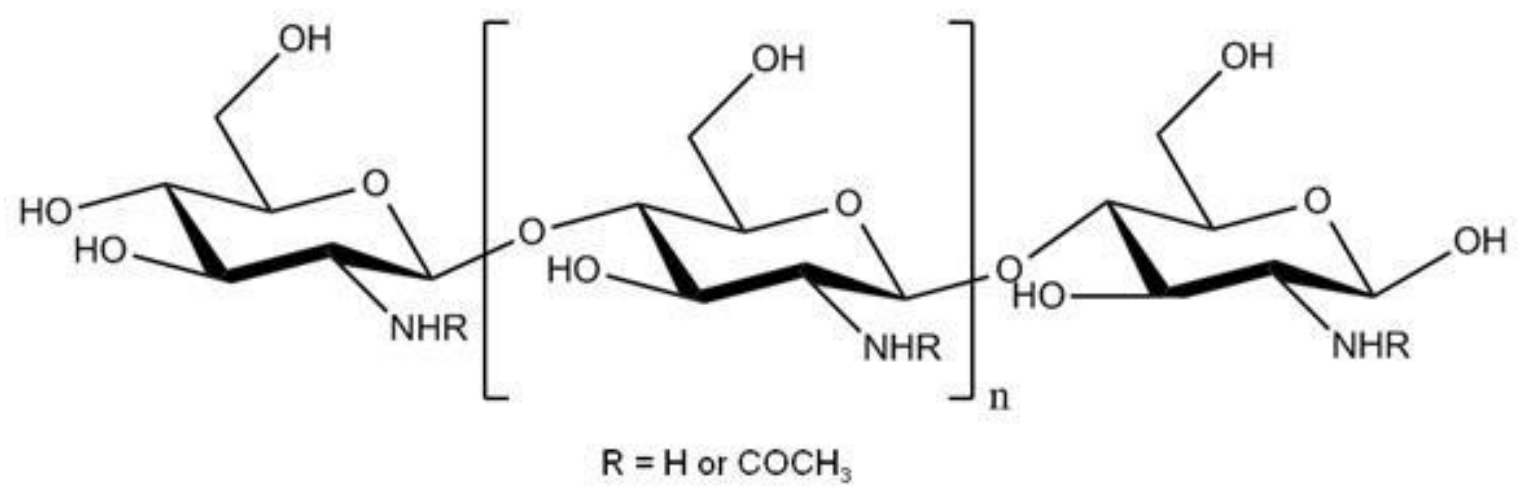

Figure 8: The chemical structure of chitosan

The amine residues along the chain have a pKa of around 6.5, and chitosan is insoluble at pHs above this [82]. Like alginate, chitosan is available commercially in a wide range of molecular weights, from tens to thousands of kilodaltons $[83,84]$. The rigidity of this polymer can be relatively high, dependent on the solvent system[85].

Many papers report the effect of chitosan coating on the viability of probiotics in simulated gastric juice, describing differing results. Two publications described a significant protective effect seen by coating the alginate microcapsules with chitosan $[53,77]$. One of these, by Cook et al, showed that chitosan coating gave survival levels of several orders of magnitude greater than alginate alone. Additionally, this protective effect was not lost after drying the microcapsules using fluid bed drying (Figure 9) [53]. The increased cationic nature (and therefore ability to buffer acid) of chitosan 
relative to alginate may explain this increase in protection. Another study, however, which examined microencapsulated yeast with a chitosan coating found that there was an improvement in the survival of yeasts in high acidic conditions after alginate encapsulation, but that the addition of a chitosan coat did not improve the survival. This study was conducted with both in vitro and in vivo experiments [49] the latter involving the enumeration of live yeast in the faeces of Wistar rats fed the yeast in its encapsulated and non-encapsulated form. A possibility for the discrepancy seen here is the relatively high acid tolerance of the yeast used(approximately $2 \log$ (CFU)/g over $120 \mathrm{~min}$ at pH 1), and that encapsulation in either of the systems only led to a marginal increase in cell survival. Another study, by Lin et al [86] coated alginate microcapsules with chitosan or poly-l-lysine, followed by a further layer of alginate. This ability of these capsules to protect an $E$. coli strain from acid was determined and it was found that coating these microcapsules did not increase the number of cells surviving exposure to acid. Again, the strain of bacteria used had a quite high tolerance to acid, with an approximately 1 log (viable cells)/ml decrease over $120 \mathrm{~min}$ at $\mathrm{pH} 2$.

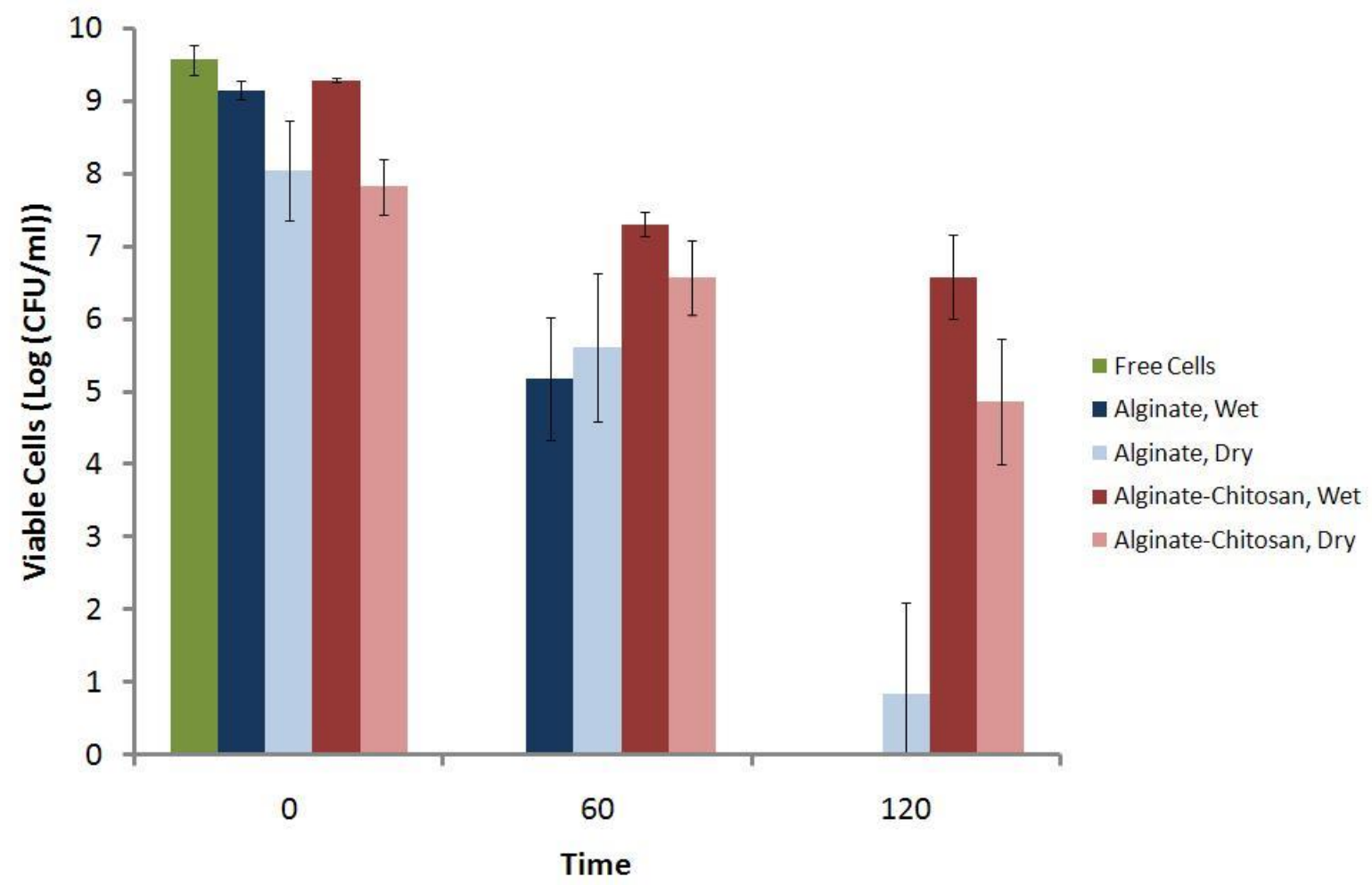

Figure 9: Effect of encapsulation in alginate, and alginate-chitosan microcapsules on the survival of Bifidobacterium breve in simulated gastric solution compared to free cells. The data show both wet and fluid bed dried microcapsules. Reprinted with permission from Biomacromolecules 2011, 12, 2834-2840 [53]. Copyright (2011) American Chemical Society

Besides chitosan, other less common coating materials have also been used. Gbassi et al [78] have reported the use of whey protein to coat wet alginate microcapsules containing Lactobacillus plantarum; this resulted in an improvement in the survival of the probiotic by $6 \log (\mathrm{cfu} / \mathrm{mL})$ after 90 minutes exposure to simulated gastric juice. The rationale behind this is that the whey protein provides a layer around the microcapsule which cannot be degraded in the stomach. Another coating material used to improve cell viability during gastric passage is palm oil, used by Ding et al [37], which is heated to just above its melting point, and then allowed to cool around the 
microcapsules; this provides a hydrophobic layer around the microcapsule, reducing the rate of water uptake and therefore the rate of cell death, although this protective effect does not seem as great as with chitosan. Alginate microcapsules have also been coated with the homo-polypeptide poly-L-lysine to reduce clumping [37]. The incorporation of cellulose acetate phthalate and xanthan gum [68], starch [69] and gelatin [75] into the alginate mixture have also been investigated, and showed potential for improving the survival of probiotics during their passage through the GI tract. For instance, Albertini et al [68] have shown that incorporation of xanthan gum or cellulose acetate phthalate improved the survival of Lactobacillus acidophilus LA14 and Bifidobacterium lactis BI07 in gastric juice by around $7 \%$ relative to alginate alone. In addition, these excipients can impart favourable qualities other than increasing gastric survival. This is exemplified by Chan et al [87] who incorporated starch as a 'filler' for alginate microcapsules, providing improved shape and hardness to the microcapsules. Additionally, mixed polysaccharide microcapsules have been produced by a number of groups. These have examined systems containing alginate blended with starch [74], cellulose acetate phthalate [68], or xanthan gum [68] which have all shown potential for improving the survival of probiotics during their passage through the gastrointestinal tract.

\section{Encapsulation in Other Polysaccharides}

Other polysaccharides have been less widely used than alginate for the encapsulation of probiotics, but nevertheless a number of these show good potential as encapsulation matrices for protecting encapsulated bacteria from the harsh acid and bile conditions of the stomach.

The most commonly used gum is xanthan, a heteropolysaccharide consisting of polypentasaccharide groups formed from 2 glucose, 2 mannose and 1 glucuronic unit [88], with its polymer backbone consisting of $1 \rightarrow 4$ linked $\beta$-(D)-glucose units (Figure 10).

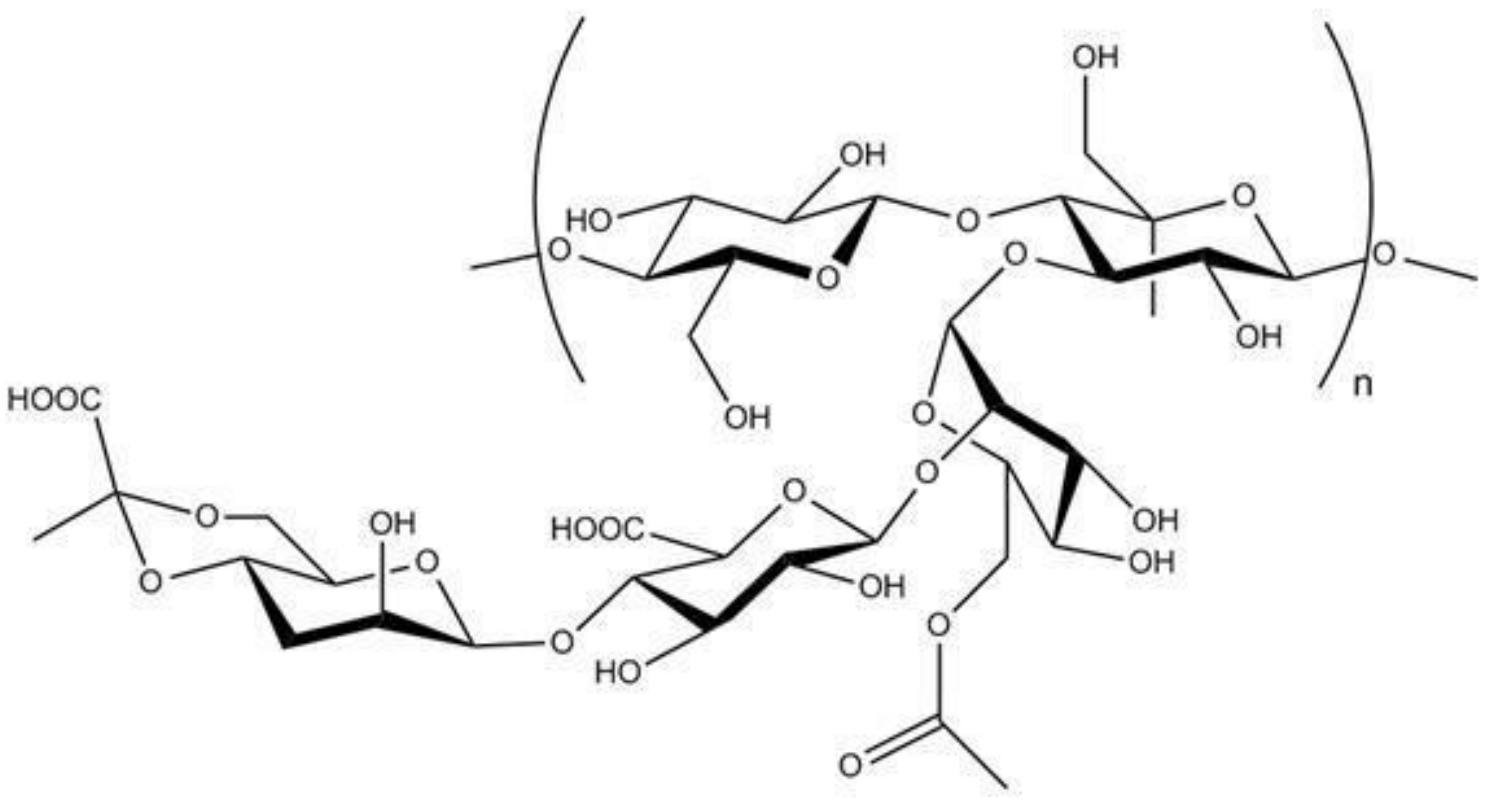

Figure 10: The structure of xanthan gum 
Xanthan gum's efficacy as an encapsulating material on its own has been investigated [72]. Microcapsules were produced by the emulsion method in which the discrete water phase, containing xanthan gum was cross-linked with calcium chloride whilst suspended in oil. These microcapsules offered a level of protection to bile and acid (at $\mathrm{pH} 2$ ) comparable to that of alginate. This polymer is also akin to alginate in terms of its ability to be cross-linked with calcium ions. This property is advantageous in bacterial applications as the conditions are gentle enough not to damage the bacteria. Xanthan has also been used in combination with gellan to form acid stable microcapsules $[38,89]$. These microcapsules produced by extrusion into $\mathrm{CaCl}_{2}$ solution were of variable size, ranging from 20 microns [90] to $3 \mathrm{~mm}$ [38], depending on the size of droplets formed during extrusion. The survival of $B$. infantis and $B$. lactis in simulated gastric juice was vastly improved by the microencapsulation process. Under these conditions, the viability of non encapsulated $B$. infantis decreased from $10 \mathrm{log}$ cells $/ \mathrm{ml}$ to 0 over half an hour, whereas the viability of encapsulated $B$. infantis decreased by only $0.67 \mathrm{log}$ cells $/ \mathrm{ml}$. A more unusual example of the use of xanthan in microencapsulation is the encapsulation of Pediococcus acidilactici in an emulsion using xanthan as a surfactant [73]. It was found that not only did this encapsulation procedure improve the cell viability in simulated gastric juice, but it also broke down in the simulated intestinal juice, indicating a possibility for effective intestinal delivery.

Another gum that has been reported as having the ability to protect the cells from acid is gum acacia [91]. Gum acacia (or gum Arabic) has a very complex structure, having three main components. The largest component is a polysaccharide moiety comprised of a $1 \rightarrow 4$ linked galactose backbone with arabinose and rhamnose branches, terminating with a glucuronic acid monomer. The next largest component is a covalently attached arabinogalactan-protein complex; this is responsible for around $10 \%$ of the total polymer. The smallest fraction is a glycoprotein, taking up $1 \%$ of total weight [92]. Desmond et al spray dried $L$. casei with gum acacia [91], and a good protection was demonstrated in vitro using gastric fluids taken from pigs, however, survival during the drying process was very low (around 1\%) though this has the potential to be increased by the use of lyoprotectants. Microencapsulation by spray drying with gum acacia has also been shown to offer protection to bifidobacteria [93]. Other gums used as immobilization matrices are guar gum, locust bean gum, and carrageenan [72], all of which showed some protective effect for the ten strains of probiotic bacteria investigated [72] (Figure ). 


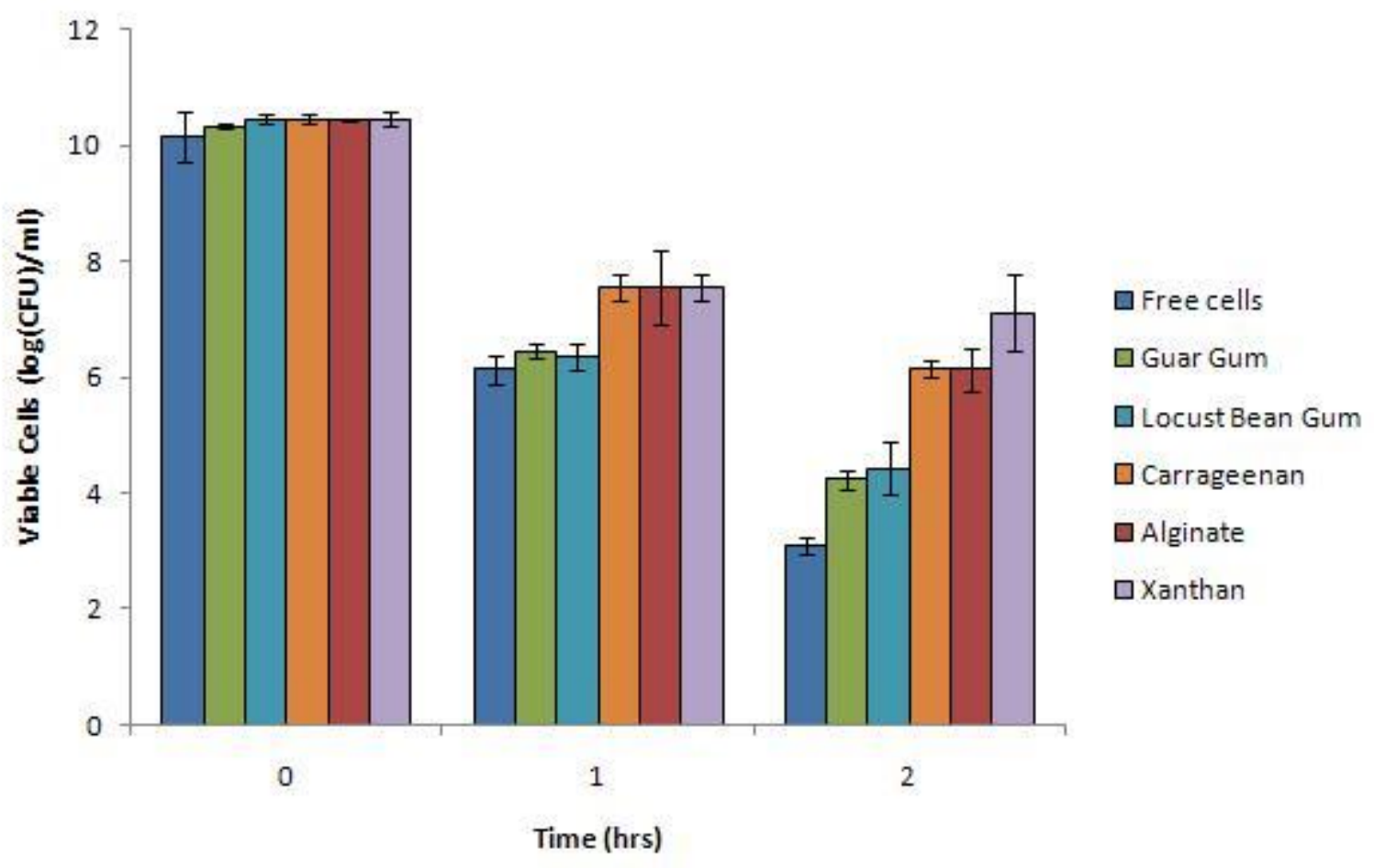

Figure 11: Effect of various encapsulation matrices on the survival of $L$. rhamnosus in a $\mathrm{pH} 2$ solution. Graph constructed from data taken from Journal of Food Science 2009, 74, M100-M107 [1] with permission from John Wiley and Sons. Copyright (2009) John Wiley and Sons

\section{Encapsulation in Proteins}

Proteins have become, especially in the last few years, a popular choice for encapsulation of probiotics. Proteins have very large, complex structures but may be gelled using enzymatic crosslinking, heat controlled sol-gel transition or chemical cross-linking. Commercially available proteins include casein, bovine serum albumin and soy protein. An example of the covalent binding of proteins is the encapsulation of $B$. adolescentis in gelatin cross-linked with genipin [94], a naturally occurring fruit extract, which is used mainly for covalently binding amino groups [95]. The ability of the prepared microcapsules ( $<100$ microns) to protect bacteria in simulated gastrointestinal conditions was investigated with, and without, coating with maltodextrin. The encapsulation process was based on an emulsion procedure relying on the phase separation of gelatin and maltodextrin as the emulsion cools. It was found that as the concentration of genipin increased, the dissolution time of the microcapsules increased, as one would expect due to the higher level of cross-linking. It was also shown that encapsulation with gelatin and cross-linking with genipin reduced the rate of cell death in simulated gastric juice, and that the maltodextrin coated microcapsules offered better protection still. There was also an increase in the viability seen in larger microcapsules, consistent with previously reported results for alginate.

Casein, a milk protein has been used in a few cases as a water insoluble (below $\mathrm{pH}$ 6) matrix for protecting bacteria during gastric transit. In one application, L. paracasei and B. lactis were encapsulated by covalent linking of the glutamine and lysine moieties of casein using the enzyme transglutaminase [96]. The transglutaminase was added to the casein cell mixture, which was emulsified and heated to induce cross-linking. This process improved cell viability in $\mathrm{pH} 2.5$ buffer by $20 \%$ relative to the free cells. Milk proteins are particularly popular as encapsulating materials as 
non-milk based materials are less desirable, or in some cases are not allowed in dairy products, the common vehicle for probiotics. Skimmed-milk has been utilised in microencapsulation by using rennet to gel the proteins contained in the milk [44]. This improved the survival of $B$. lactis from $0.01 \%$ (in free form) to just over $10 \%$ in $\mathrm{pH} 2.5$ solution. Oliveira et al [45] have also used casein in combination with pectin to form coacervates which were then spray dried. This encapsulation procedure resulted in an impressive increase in cell survival in $\mathrm{pHs}$ as low as 1 , for both Lactobacillus acidophilus and Bifidobacterium lactis. Other research has focussed on whey proteins and milk fats as encapsulation materials [97]. In these cases the materials were emulsified and spray dried. It was found that the survival during spray drying was dependent on the strain of bacteria used, but that once microencapsulated, the probiotic's viability during a simulated gastric digestion experiment was improved. The effect of various parameters on the survival of a probiotic during spray drying with whey protein has also been investigated by Ying et al [98]. Doherty et al [99] have demonstrated that microbeads comprised of whey protein isolate imparted very good cell survival to Lactobacillus rhamnosus $\mathrm{GG}$ exposed to ex vivo porcine gastric contents, determined by fluorescence-activated cell sorting. These bacteria were not only viable, but retained their activity after exposure to gastric contents. An alternative approach to encapsulation using whey protein has been described by López-Rubio et al [100], in which Bifidobacterium animalis subsp. lactis Bb12 were mixed with the protein before electro-spraying or electro-spinning. This process produced protein capsules with diameters of under 8 microns. These capsules were evaluated for their ability to keep the bacteria viable during storage, but not taken to testing their ability to protect the bacteria from acid. Whey protein and pectin capsule have been examined by Gerez et al [101], in which it was found that the coating of a pectin matrix, formed by ionic gelation, with whey protein increased the microcapsule's ability to protect Lactobacillus rhamnosus from $\mathrm{pH}$ as low as 1.2. However, it was seen that the incorporation of whey protein into the pectin matrix reduced the protective effect of the capsules. This reduction of efficacy was put down to poorer association of the coating material to the capsules, though it is also possible that the whey protein interfered with the gelation of the pectin, producing a weaker gel with a higher swelling capacity.

\section{Modified release of probiotics}

The addition of coats or the blending of polymers has the potential to impart a modified release to probiotic microencapsulation systems. As mentioned previously, probiotic bacteria are typically too large to diffuse out of microparticles so the addition of these excipients should result in a modification of the rate or conditions of dissolution in order to change the release characteristics of microencapsulation systems.

In pharmaceutical applications, the coating of alginate microspheres with chitosan leads to the 'controlled' (as opposed to 'burst') release of entrapped drugs in simulated intestinal conditions [102]. This effect has also been noted with respect to probiotic encapsulation [79], though not as strongly. It has been shown that chitosan coated alginate microcapsules are able to retain encapsulated bacteria during exposure to simulated gastric solutions, before releasing them steadily in simulated intestinal solutions for over two hours [53] (Figure 12). This time scale would allow for a control of release over the small intestine, but not to the farthest regions of the large colon, which would be a target for ulcerative colitis therapy [103]. Lin et al [86] have conducted some in vivo studies on the stability of alginate microcapsules containing $E$. coli DH5 which have been coated either chitosan or poly-I-lysine, followed by a second coat of alginate. These microcapsules were administered to Wistar rats, before being excised after 6 hours digestion. Qualitative information was then gathered by examination of the capsules using light microscopy. The chitosan coated 
particles seemed to show a better resistance to digestion than those coated with poly-I-lysine, but further quantitative data would be needed to strengthen conclusions.

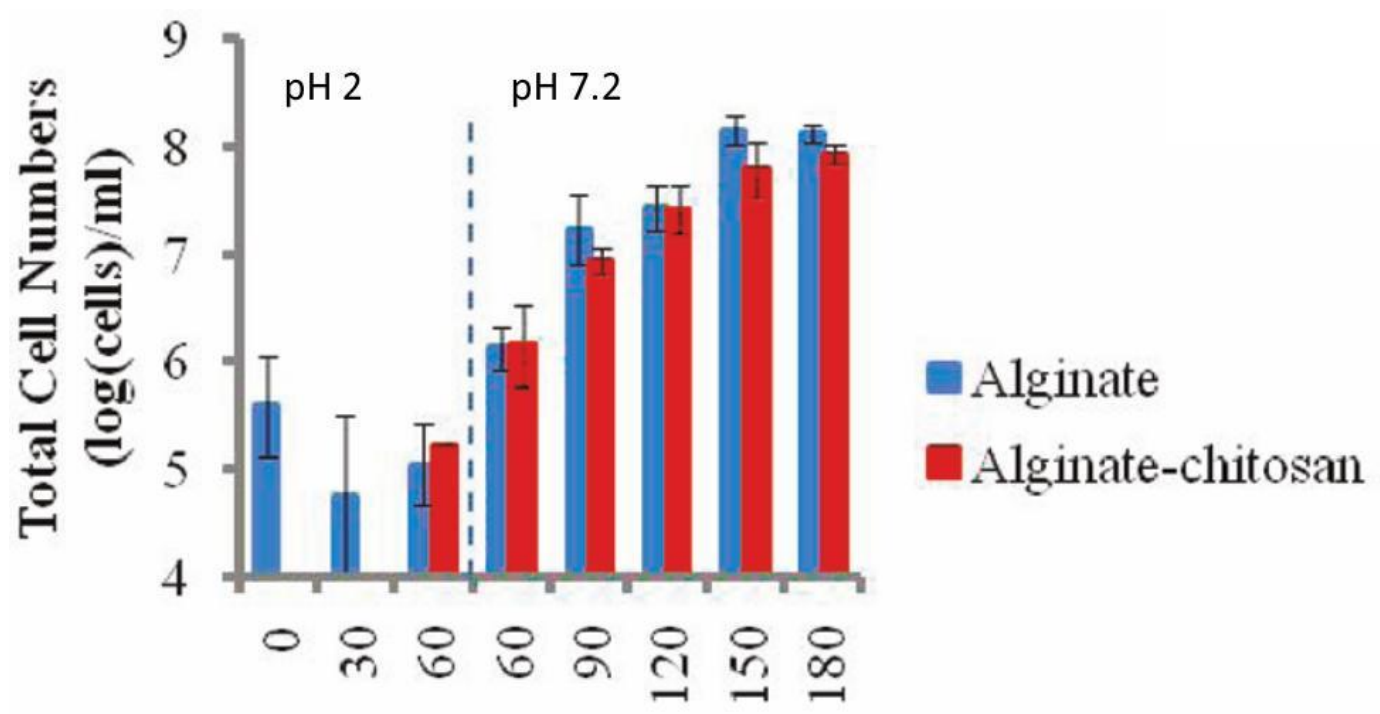

\section{Time (min)}

Figure 12: Release of Bifidobacterium breve from alginate (red) and alginate-chitosan (blue) microcapsules during exposure to simulated gastric juice $(60 \mathrm{~min})$ followed by simulated intestinal juice (120 min). Measurements were taken using total cell counts on a light microscope in phase contrast mode. Reprinted with permission from Biomacromolecules 2011, 12, 2834-2840 [47]. Copyright (2011) American Chemical Society

There has been some research by Zhou et al [104] on the release of lactic acid bacteria from alginate into milk. This research showed that as the initial level of cell loading was increased the rate of release of cells from alginate matrices into milk increased. It was also found that a decrease in molecular weight of chitosan resulted in a decreased rate of cell release, as a result of increased penetration of chitosan macromolecules into the alginate matrix. These parameters may also affect release in the $\mathrm{Gl}$ tract.

There has been little published data on the rates or conditions of release of probiotics from protein matrices in $\mathrm{Gl}$ conditions. The release would most likely be a result of protein denaturation at low $\mathrm{pH}$ [105] or by cleavage of amide bonds by the enzymes pepsin and trypsin [106] (located in the stomach and duodenum, respectively), resulting in a breakdown of the matrix and release of the bacteria. Li et al [75] have, reported the incorporation of gelatin into alginate microcapsules which did not adversely affect the nature of release. Borza et al [88] have described the degradation of genipin cross-linked gelatin incorporating maltodextrin in simulated gastric juice. Their data suggests that the rate of dissolution is proportional to the degree of cross-linking, and that increasing gelatin concentration resulted in an increase in dissolution time in simulated gastric juice. These results imply that bacteria should not be released in the stomach under certain conditions. There is opportunity for further experimentation to determine release profiles in more complex in vitro models. Doherty et al [107] have extensively evaluated the production of whey protein microbeads encapsulating Lactobacillus rhamnosus GG, describing their stability in simulated gastric juice, followed by dissolution in simulated intestinal juice. The published data showed a surprising stability of microbeads to both acid and pepsin. Continued research by this group [99] demonstrated 
potential targeted delivery to the intestine by the exposure of microencapsulated Lactobacillus rhamnosus GG to ex vivo porcine stomach and intestinal contents (Figure 13). The experiment showed that there was minimal loss of probiotic during incubation in stomach contents, but a release over $30 \mathrm{~min}$ in the contents of the intestine. Interestingly, the release of bacteria was not noted in phosphate buffered saline $(\mathrm{pH} 7)$, so the release was put down to a synergistic effect between $\mathrm{pH}$ and enzymatic activity of the porcine intestinal contents.

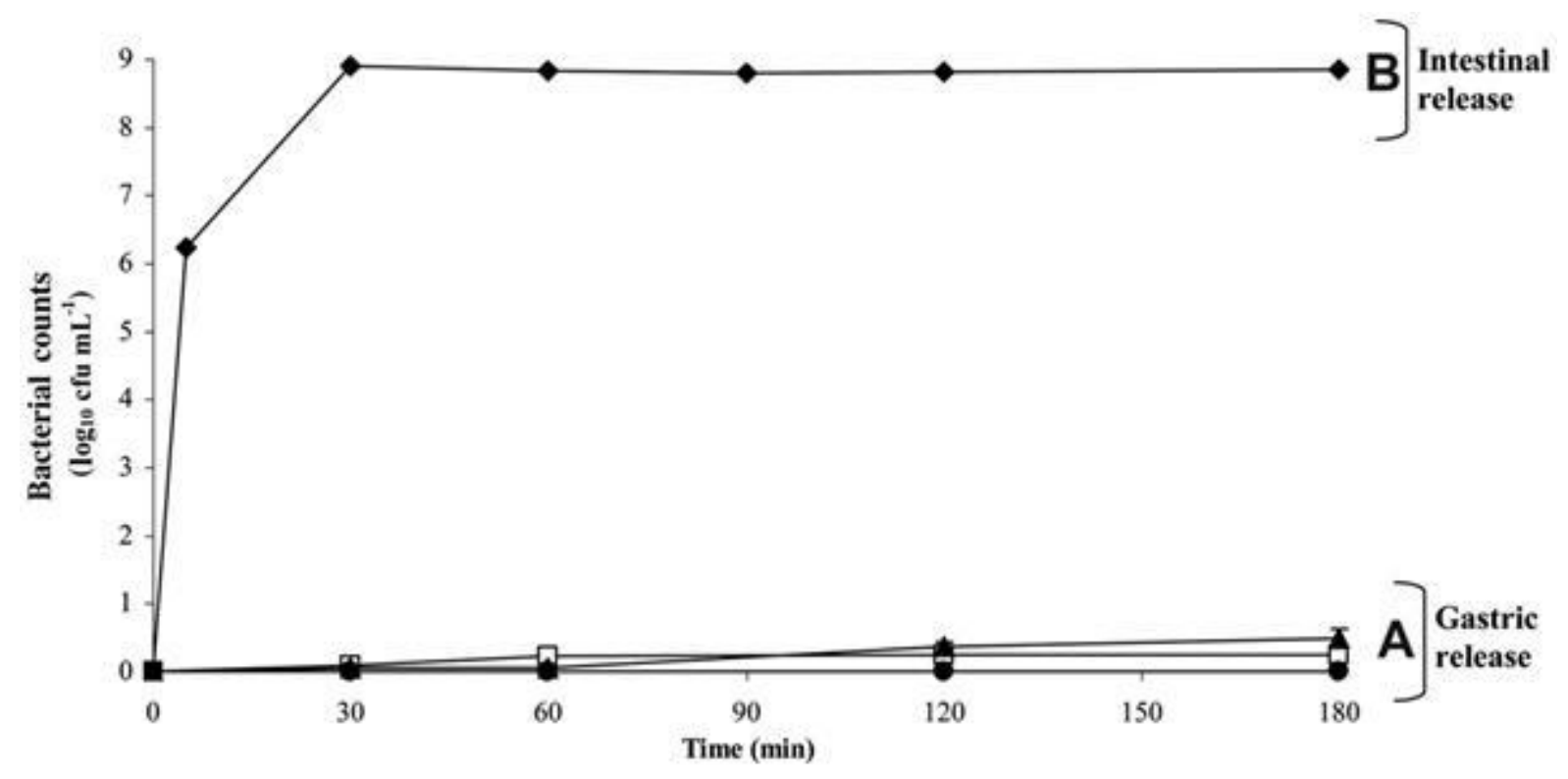

Figure 13: Release of Lactobacillus rhamnosus from whey protein isolate microcapsules during exposure to (A) ex vivo gastric contents at pH 3.4 (filled circle), pH 2.4 (empty square) and pH 2.0 (filled triangle) and (B) ex vivo intestinal contents at $\mathrm{pH} 6.6$ (filled rhombus). Reprinted with permission from International Dairy Journal 2012, 22, 31-43 [92]. Copyright (2011) Elsevier.

Shellac, a complex, insect-derived, resin has been used by Hamad et al [108] to entrap a probiotic yeast, Saccharomyces Cerevisiae, in order to control its release. The microbes were entrapped by either spray-drying or by precipitation of the shellac. Once produced, the microcapsules showed a $\mathrm{pH}$ dependent dissolution profile, with dissolution occurring more rapidly as the $\mathrm{pH}$ was increased from 6.5 to 9. The capsules were shown to protect Saccharomyces cerevisiae from $0.1 \mathrm{M} \mathrm{HCl}$ solution by a fluorescent-dye assay. Whilst this material looks very promising more in vitro studies will be needed to determine the release profile of the particles, as well as to quantify the protective effect. If this system is to be used for probiotic bacteria then much more experimentation will be needed to determine if these much less resistant species survive the encapsulation process and then exposure to acid.

\section{Methodologies for testing GI behaviour of microencapsulated bacteria In vitro methodologies}

The initial evaluation of a novel microencapsulated system will most likely be in vitro. The majority of the literature currently published in this area uses very simplified models of human GI tracts, and comparison of the literature is sometimes difficult due to inconsistencies in the composition and $\mathrm{pH}$ of the simulated GI solutions. The most commonly used simulated gastric solutions are based on the 
United States Pharmacopeia recipe, using solutions of $\mathrm{HCl}$ and salts at around $\mathrm{pH} 1.0$ to $2.0[77,109$, 110]. There are also some studies using acidified growth media [111]. Whilst these solutions are useful for proof of concept work, if serious consideration was given to human trials, validation by a more rigorous in vitro testing methodology would give the researcher a much better idea of the efficacy of their formulation in vivo. There are a variety of model digestion systems currently used in food science which simulate passage through both the stomach and intestine. For example, Marteau et al [112] have validated an in vitro multi-compartmental simulation of the stomach and small intestine for testing the survival of lactic acid bacteria during digestion. The model is divided into 4 compartments simulating the stomach, duodenum, jejunum and ileum. In order to use this method, a sample containing the probiotic strain to be studied is first suspended in a simulated saliva solution $\left(0.62 \%(\mathrm{w} / \mathrm{v}) \mathrm{NaCl}, 0.22 \%(\mathrm{w} / \mathrm{v}) \mathrm{KCl}, 0.02 \%(\mathrm{w} / \mathrm{v}) \mathrm{CaCl}_{2}\right.$, and $0.12 \%(\mathrm{w} / \mathrm{v}) \mathrm{NaHCO}_{3}$ ) which is then injected into the digestion vessel, kept at $37^{\circ} \mathrm{C}$. After this injection a secretion of pepsinogen (370 units $/ \mathrm{ml}$ ) and a $1 \mathrm{M} \mathrm{HCl}$ polyelectrolyte solution is added gradually. The rate of acid addition, and therefore $\mathrm{pH}$, within the digester is controlled by a computer which in this case was gradually lowered from pH 5.0 to 1.8 over an 80 minute period, exposing the contents to the range of $\mathrm{pH}$ found in the stomach. Flow out of this gastric chamber was regulated by computer via a pump to give a half emptying time of 70 minutes. As previously stated, half emptying time has been estimated at 80.5 minutes [26], which correlates fairly well with this data. As the partially digested materials passed into the small intestinal compartments, $\mathrm{pH}$ was raised to $\mathrm{pH}$ 6.5. The duodenal compartment contained additional secretions composed of $7 \%(\mathrm{w} / \mathrm{v})$ pancreatin, $0.3 \mathrm{M} \mathrm{NaHCO}_{3}$ and bile, the concentration of which was lowered over time. Dialysis devices were connected to the jejunal and ileal compartments which contained $0.5 \%(\mathrm{w} / \mathrm{v})$ of $\mathrm{NaCl}, 0.06 \%(\mathrm{w} / \mathrm{v}) \mathrm{KCl}, 0.03 \%(\mathrm{w} / \mathrm{v})$ of $\mathrm{CaCl}_{2}$, and, in the case of the jejunal compartment, $1.55 \%(\mathrm{w} / \mathrm{v})$ bile. This digestive simulation is a continuous process, and in this case samples were taken over a 6 hour period. The number of viable bacteria found at the end of the simulated digestion had a good correlation with data taken from 6 human volunteers [113]. However, it appeared that the viable cells were, in this case, reaching the end of the small intestine at a faster rate in simulated digestion than in vivo. This could be easily rectified by the adjustment of flow rates. This method looks to be a carefully planned and effective way of studying the survival of probiotics, offering good control over the conditions used, and thus has possible application to the study of microencapsulated products.

Whilst the model of Marteau et al[112] provides a complex chemical environment for the study of probiotics, there is an argument that the addition of a strain of bacteria into the highly varied intestinal microbiota will have a larger effect on the microbial community found within than just the counting of viable cells demonstrates. To study this further, the SHIME (Simulator of the Human Intestinal Microbial Ecosystem) was devised by Molly et al $[114,115]$. This system, when first devised was comprised of 5 vessels containing a complex medium, inoculated with faecal matter which simulated the duodenum, jejunum, ileum, ascending colon, tranverse colon, and the descending colon. The contents of these vessels could be evaluated in terms of bacterial enumeration, enzymatic activity and bacterial activity, amongst other things. It also contains an 'electronic nose' which gives information on the vapours present in the digestion vessels. De Boever et al [116] , from the same research group, altered the SHIME system to include a vessel simulating the stomach's activity, which is more useful for the subject of this review. This alteration gave a final system comprising of a simulated stomach (1), small intestine (2), ascending colon (3), tranverse colon (4), and descending colon (5) (Figure 14). The SHIME system is inoculated with human faecal matter into the 3 colonic vessels and 'fed' thrice daily with a carbohydrate medium containing $0.1 \%$ $(\mathrm{w} / \mathrm{v})$ arabinogalactan, $0.2 \%(\mathrm{w} / \mathrm{v})$ pectin, $0.1 \%(\mathrm{w} / \mathrm{v})$ xylan, $0.3 \%(\mathrm{w} / \mathrm{v})$ starch, $0.04 \%(\mathrm{w} / \mathrm{v})$ glucose and $0.4 \%(\mathrm{w} / \mathrm{v})$ porcine gastric mucin. The $\mathrm{pH}$ in SHIME is controlled using $0.1 \mathrm{M} \mathrm{HCl}$ or $\mathrm{NaOH}$ electronically, maintaining the vessels at $\mathrm{pH}$ 2.0-2.5, 5.0-6.0, 5.5-6.0, 6.0-6.4 and 6.6-6.9 for vessels 1-5 in order. The gastric and colonic $\mathrm{pH}$ values correspond well with those discussed earlier 
in the literature, though the simplified small intestine in this case does not provide as extensive a range of conditions as their previous model. The vessel simulating the small intestine (2) is also supplemented with $100 \mathrm{ml}$ of a solution containing $0.09 \%(\mathrm{w} / \mathrm{v})$ pancreatin, $0.6 \%(\mathrm{w} / \mathrm{v})$ bile salt and $1.26 \%(\mathrm{w} / \mathrm{v}) \mathrm{NaHCO}_{3}$ to better simulate the in vivo environment. The retention time for the entire system is 88 hours, quite a lengthy digestive period, though this could be tailored for the individual's experiment. When performing SHIME, efforts are made to keep the digestion vessels purged with nitrogen and maintained at $37^{\circ} \mathrm{C}$. SHIME was shown to display close microorganism-associated activity to in vivo tests [115]. For application to microencapsulated probiotic systems, SHIME could be combined with bacterial enumeration in each chamber to quantify both the survival and release of bacteria from the formulations, the presence of faecal microflora within the chambers means that the enumeration step must be carefully planned in order to ensure success.

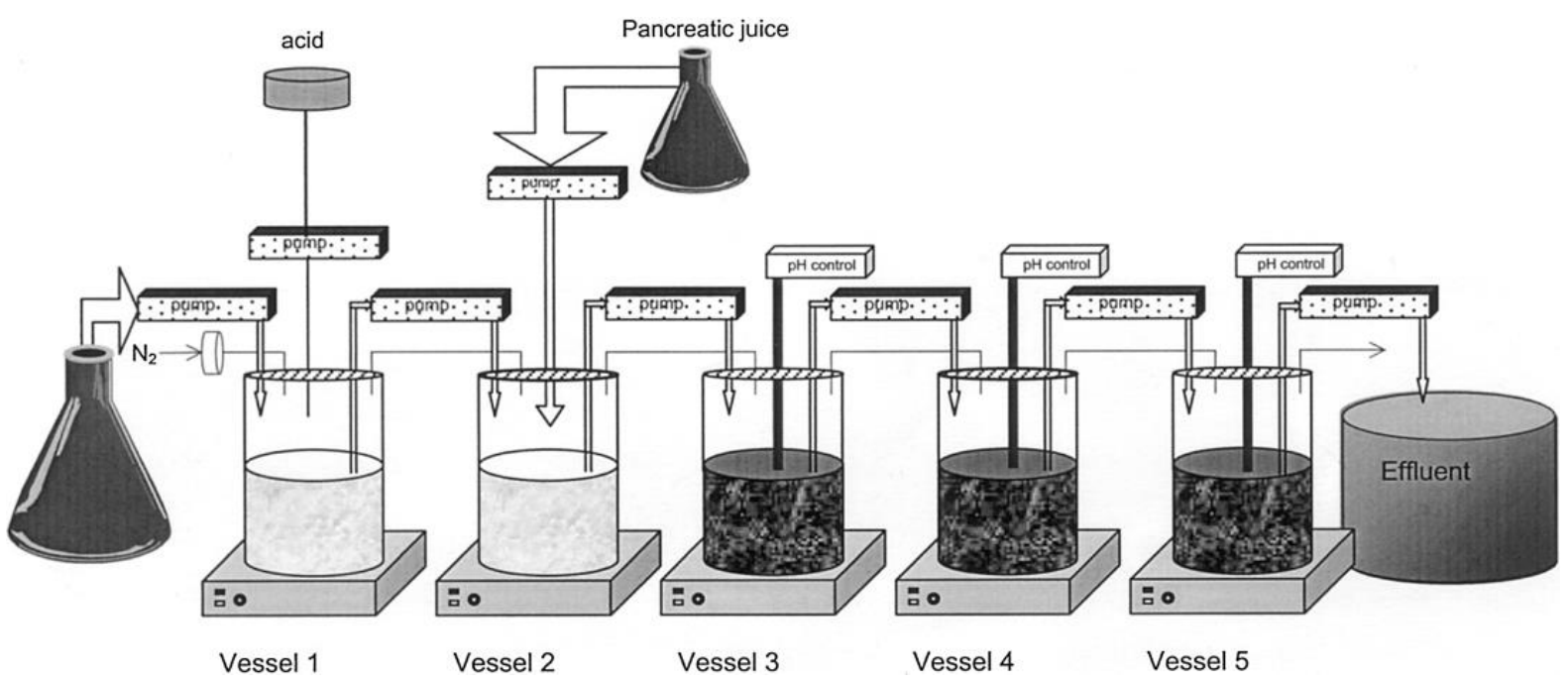

Figure 14: Schematic outline of the SHIME system, developed by De Boever et al [116]. The 5 vessels simulate the stomach, small intestine, ascending colon, transverse colon and the descending colon, in that order. Image reprinted with permission of the author.

\section{In vivo methodology}

The application of in vitro tested materials to in vivo systems would undoubtedly provide the most informative findings for the researcher. By far the most commonly used laboratory animals in probiotics research are rodents, though there are studies published on their effect in larger mammals. A comprehensive review of laboratory animal's GI physiology has been published by Kararli [117]. From this review he draws the conclusion that there is no animal model which provides ideal characteristics for mimicking the whole of the human GI tract. He does state, however, that 'dogs and humans have similar stomach morphology and emptying characteristics' whilst 'pig and human colon morphology appears similar'. This demonstrates a need to carefully plan animal experimentation in order to maximise the gains of the study.

In vivo trials of microencapsulated probiotics may be approached with two different philosophies. Firstly, the counting of a specific strain of probiotic bacteria in the animal may be undertaken using a variety of molecular biology techniques [118], such as Fluorescence In-Situ Hybridisation (FISH) [119] and Polymerised Chain Reaction (PCR) [120]. FISH is the most commonly used technique for the identification of a specific strain from a mixture and requires less instrumentation than PCR. For those unfamiliar with the technique, FISH relies on the association of a probe which has a high specificity for a particular gene sequence onto the bacteria's DNA. This probe is tagged with a fluorophore which allows counting of the specific cells by fluorescence microscopy or flow cytometry. The study of an orally administered probiotic's ability to inhabit the intestinal tract can 
be investigated using a similar method to Graff et al [49] and Kushal et al [121]. In these studies the number of cells of a delivered strain of bacteria in rats or mice was quantified during a feeding study by enumeration of the specific species in the faeces of the animal during the course of the experiment. In a similar experiment on free probiotics by Lan et al [122], this was followed by excision of the caecum and cell counting of the contents at the end of the study. Alternatively, the distribution of a probiotic could be measured by the killing of the animals at various stages of digestion, and subsequent FISH experiments on the contents of the GI tract. This would give a much better understanding of the biodistribution of the probiotic and therefore the release profile of the formulation. However, this method would require many more animals. Studies involving larger animals, such as pigs, have also been conducted on the effect of probiotics, which could be expanded to microencapsulated bacteria. For instance, Tzortzis et al [123]studied the effect of a 'prebiotic', a mixture of oligosaccharides capable of promoting the growth of specific probiotics in the host's intestine. To perform this study, male pigs were fed a prebiotic supplement over a 4 week period, at the end of this they were killed and their large intestines excised. These intestines were divided into proximal and distal regions and further experiments performed. The numbers of different bacteria species were determined by FISH, the short chain fatty acids produced by bacterial fermentation quantified and the $\mathrm{pH}$ measured. This method also gives some idea of the areas of populated by the bacteria, which may be affected by a controlled release agent.

Another possible approach to in vivo work is to be more pragmatic and indirectly measure the efficacy of a microencapsulation system by detecting the activity of the microbe in the host. For instance, Fitzpatrick et al [124] induced colitis into mice using dextran sulphate sodium before treating them with a probiotic. The severity of induced colitis was measured on a previously defined disease activity scale, and the effect of a probiotic administration determined. This experiment design could be used as a control for a larger experiment, in which the animals are also given a microencapsulated product. Another study, by Zani et al [125] measured the ability of a probiotic to decrease the instances of diarrhea in infant pigs. This particular study is also advantageous if you wish to avoid the killing of the animals.

Though currently there are no published trials on the effect of microencapsulated probiotics on humans, there are many on probiotics alone. As a result of this it may be easier to gain permission for these trials than it would be for a novel drug. This would speed up the process of bringing any microencapsulated products to market. These trials would have to be undertaken by examination of a specific species in the subject's faecal matter, by measurement of indicators of microbial acitivity or by the alleviation of specific symptoms, such as diarrhea, in the host.

\section{Concluding remarks}

Microencapsulation has the potential to be a useful tool in improving the survival of probiotics over the course of the gastrointestinal tract, whether in polysaccharide or protein based systems. However, there is still room for improvement in terms of bacterial survival at low pHs, as well as focusing the research more in controlling the release from the capsules. The nature of the probiotic's release is of particular importance as without knowing this, the percentage of the bacteria delivered may be considerably less than that administered. The nature of release may also be tailored dependent on which sort of probiotic effect is intended to be exploited. Delivery to the small intestine would favour immune response whereas the colon is the traditional site of antipathogenic action. Currently, the majority of published data contains no information on the nature of release allowing many opportunities for further research. In particular, digestion of an encapsulation matrix by the colonic microflora may be a better method of targeting release to the colon than $\mathrm{pH}$. In order to advance the science of probiotic microencapsulation it is important that 
new polymers are put forward as either coats or new encapsulation matrices, though this is hampered by the need for GRAS certification from the regulatory authorities. In traditional alginate based systems, the decrease in protection as particle size decreases is troublesome, so this may need to be overcome by adding excipients into the gels, with a view to increase the protection of the bacteria. As summarised above, drying methods may need to be examined if we wish to bring any of these products to market. In addition, a greater number of in vivo studies will need to be carried out in order to confirm the efficacy of these formulations. The limited in vivo data from Wistar rats and mice are promising $[49,121]$, but there are no data available in animal models closer to the human physiology, such as pigs. The next step would be the use of clinical trials to examine efficacy in a human model.

\section{References}

[1] R. Fuller, Probiotics in man and animals, Journal of Applied Bacteriology, 66 (1989) 365-378. [2] S. Salminen, C. Bouley, M.C. Boutron-Ruault, J.H. Cummings, A. Franck, G.R. Gibson, E. Isolauri, M.C. Moreau, M. Roberfroid, I. Rowland, Functional food science and gastrointestinal physiology and function, British Journal of Nutrition, 80 (1998) S147-S171.

[3] L.V. Holdeman, I.J. Good, W.E.C. Moore, Human fecal flora - variation in bacterial composition within individuals and a possible effect of emotional stress, Applied and Environmental Microbiology, 31 (1976) 359-375.

[4] G.R. Gibson, M.B. Roberfroid, Dietary Modulation of the human colonic microbiota - introducing the concept of prebiotics, Journal of Nutrition, 125 (1995) 1401-1412.

[5] M.H. Saier, N.M. Mansour, Probiotics and prebiotics in human health, J. Mol. Microbiol. Biotechnol., 10 (2005) 22-25.

[6] T. Mach, Clinical usefulness of probiotics in inflammatory bowel diseases, Journal of physiology and pharmacology : an official journal of the Polish Physiological Society, 57 Suppl 9 (2006) 23-33. [7] L. O'Mahony, J. McCarthy, P. Kelly, G. Hurley, F.Y. Luo, K.S. Chen, G.C. O'Sullivan, B. Kiely, J.K. Collins, F. Shanahan, E.M.M. Quigley, Lactobacillus and Bifidobacterium in irritable bowel syndrome: Symptom responses and relationship to cytokine profiles, Gastroenterology, 128 (2005) 541-551.

[8] P.R. Marteau, M. de Vrese, C.J. Cellier, J. Schrezenmeir, Protection from gastrointestinal diseases with the use of probiotics, American Journal of Clinical Nutrition, 73 (2001) 430S-436S.

[9] B.J. Rembacken, A.M. Snelling, P.M. Hawkey, D.M. Chalmers, A.T.R. Axon, Non-pathogenic Escherichia coli versus mesalazine for the treatment of ulcerative colitis: a randomised trial, The Lancet, 354 (1999) 635-639.

[10] T. Mimura, F. Rizzello, U. Helwig, G. Poggioli, S. Schreiber, I.C. Talbot, R.J. Nicholls, P. Gionchetti, M. Campieri, M.A. Kamm, Once daily high dose probiotic therapy (VSL\#3) for maintaining remission in recurrent or refractory pouchitis, Gut, 53 (2004) 108-114.

[11] K. Kukkonen, E. Savilahti, T. Haahtela, K. Juntunen-Backman, R. Korpela, T. Poussa, T. Tuure, M. Kuitunen, Probiotics and prebiotic galacto-oligosaccharides in the prevention of allergic diseases: $\mathrm{A}$ randomized, double-blind, placebo-controlled trial, Journal of Allergy and Clinical Immunology, 119 (2007) 192-198.

[12] M. Kalliomäki, S. Salminen, H. Arvilommi, P. Kero, P. Koskinen, E. Isolauri, Probiotics in primary prevention of atopic disease: a randomised placebo-controlled trial, The Lancet, 357 (2001) 10761079.

[13] R. Fuller, Probiotics in human medicine, Gut, 32 (1991) 439-442.

[14] C.A. Adams, The probiotic paradox: live and dead cells are biological response modifiers, Nutrition Research Reviews, 23 37-46.

[15] W.P. Charteris, P.M. Kelly, L. Morelli, J.K. Collins, Development and application of an in vitro methodology to determine the transit tolerance of potentially probiotic Lactobacillus and 
Bifidobacterium species in the upper human gastrointestinal tract, Journal of Applied Microbiology, 84 (1998) 759-768.

[16] S. Mandal, A.K. Puniya, K. Singh, Effect of alginate concentrations on survival of microencapsulated Lactobacillus casei NCDC-298, International Dairy Journal, 16 (2006) 1190-1195. [17] T. Heidebach, P. Forst, U. Kulozik, Microencapsulation of probiotic cells for food applications, Crit Rev Food Sci Nutr, 52 (2012) 291-311.

[18] F. Nazzaro, P. Orlando, F. Fratianni, R. Coppola, Microencapsulation in food science and biotechnology, Current Opinion in Biotechnology, 23 (2012) 182-186.

[19] C.P. Champagne, P. Fustier, Microencapsulation for the improved delivery of bioactive compounds into foods, Curr Opin Biotechnol, 18 (2007) 184-190.

[20] S.S. Kuang, J.C. Oliveira, A.M. Crean, Microencapsulation as a tool for incorporating bioactive ingredients into food, Crit Rev Food Sci Nutr, 50 (2010) 951-968.

[21] W.R. Gombotz, S.F. Wee, Protein release from alginate matrices, Advanced Drug Delivery Reviews, 31 (1998) 267-285.

[22] M.E. Aulton, Aulton's pharmaceutics, Third Ed. ed., Elsevier, Amsterdam, 2007.

[23] D.F. Evans, G. Pye, R. Bramley, A.G. Clark, T.J. Dyson, J.D. Hardcastle, Measurement of gastrointestinal pH profiles in normal ambulant human-subjects, Gut, 29 (1988) 1035-1041.

[24] J.S. Fordtran, J.H. Walsh, Gastric-acid secretion rate and buffer content of stomach after eating results in normal subjects and in patients with duodenal-ulcer, Journal of Clinical Investigation, 52 (1973) 645-657.

[25] E.L. McConnell, H.M. Fadda, A.W. Basit, Gut instincts: Explorations in intestinal physiology and drug delivery, Int. J. Pharm., 364 (2008) 213-226.

[26] S. Hellmig, F. Von Schoning, C. Gadow, S. Katsoulis, J. Hedderich, U.R. Folsch, E. Stuber, Gastric emptying time of fluids and solids in healthy subjects determined by C-13 breath tests: influence of age, sex and body mass index, Journal of Gastroenterology and Hepatology, 21 (2006) 1832-1838.

[27] J. Janssens, G. Vantrappen, T.L. Peeters, The activity front of the migrating motor complex of the human stomach but not of the small intestine is motilin-dependent, Regulatory Peptides, 6 (1983) 363-369.

[28] S.S. Davis, J.G. Hardy, J.W. Fara, Transit of pharmaceutical dosage forms through the smallintestine, Gut, 27 (1986) 886-892.

[29] A. Coupe, S. Davis, I. Wilding, Variation in gastrointestinal transit of pharmaceutical dosage forms in healthy subjects, Pharmaceutical Research, 8 (1991) 360-364.

[30] Press, Hauptmann, Hauptmann, Fuchs, Fuchs, Ewe, Ramadori, Gastrointestinal pH profiles in patients with inflammatory bowel disease, Alimentary Pharmacology \& Therapeutics, 12 (1998) 673678.

[31] G. Sathyan, S. Hwang, S.K. Gupta, Effect of dosing time on the total intestinal transit time of non-disintegrating systems, Int. J. Pharm., 204 (2000) 47-51.

[32] M.K. Chourasia, S.K. Jain, Pharmaceutical approaches to colon targeted drug delivery systems, Journal of Pharmacy and Pharmaceutical Sciences, 6 (2003) 33-66.

[33] V.R. Sinha, R. Kumria, Microbially triggered drug delivery to the colon, European Journal of Pharmaceutical Sciences, 18 (2003) 3-18.

[34] E.L. McConnell, M.D. Short, A.W. Basit, An in vivo comparison of intestinal pH and bacteria as physiological trigger mechanisms for colonic targeting in man, Journal of Controlled Release, 130 (2008) 154-160.

[35] I.A. Sogias, A.C. Williams, V.V. Khutoryanskiy, Why is chitosan mucoadhesive?, Biomacromolecules, 9 (2008) 1837-1842.

[36] V.V. Khutoryanskiy, - Advances in mucoadhesion and mucoadhesive polymers, - 11 - 764.

[37] W.K. Ding, N.P. Shah, An improved method of microencapsulation of probiotic bacteria for their stability in acidic and bile conditions during storage, Journal of Food Science, 74 (2009) M53-M61. 
[38] W.R. Sun, M.W. Griffiths, Survival of bifidobacteria in yogurt and simulated gastric juice following immobilization in gellan-xanthan beads, Int. J. Food Microbiol., 61 (2000) 17-25.

[39] V. Chandramouli, K. Kailasapathy, P. Peiris, M. Jones, An improved method of

microencapsulation and its evaluation to protect Lactobacillus spp. in simulated gastric conditions, Journal of Microbiological Methods, 56 (2004) 27-35.

[40] J.H. Cui, J.S. Goh, P.H. Kim, S.H. Choi, B.J. Lee, Survival and stability of bifidobacteria loaded in alginate poly-I-lysine microparticles, Int. J. Pharm., 210 (2000) 51-59.

[41] Y. Senuma, C. Lowe, Y. Zweifel, J.G. Hilborn, I. Marison, Alginate hydrogel microspheres and microcapsules prepared by spinning disk atomization, Biotechnology and Bioengineering, 67 (2000) 616-622.

[42] J.S. Ryu, Y.J. Lee, S.I. Choi, J.W. Lee, T.R. Heo, Optimization of screw pumping system (SPS) for mass production of entrapped bifidus, Food Science and Biotechnology, 14 (2005) 566-571.

[43] R.R. Mokarram, S.A. Mortazavi, M.B.H. Najafi, F. Shahidi, The influence of multi stage alginate coating on survivability of potential probiotic bacteria in simulated gastric and intestinal juice, Food Research International, 42 (2009) 1040-1045.

[44] T. Heidebach, P. Forst, U. Kulozik, Microencapsulation of probiotic cells by means of rennetgelation of milk proteins, Food Hydrocolloids, 23 (2009) 1670-1677.

[45] A.C. Oliveira, T.S. Moretti, C. Boschini, J.C.C. Baliero, O. Freitas, C.S. Favaro-Trindade, Stability of microencapsulated B. lactis (BI 01) and L. acidophilus (LAC 4) by complex coacervation followed by spray drying, J Microencapsul, 24 (2007) 673-681.

[46] A.C. Oliveira, T.S. Moretti, C. Boschini, J.C.C. Baliero, O. Freitas, L.A.P. Freitas, C.S. FavaroTrindade, Microencapsulation of B. lactis (BI 01) and L. acidophilus (LAC 4) by complex coacervation followed by spouted-bed drying, Drying Technology, 25

(2007) 1687-1693.

[47] K. Jono, H. Ichikawa, M. Miyamoto, Y. Fukumori, A review of particulate design for pharmaceutical powders and their production by spouted bed coating, Powder Technology, 113 (2000) 269-277.

[48] A. Gharsallaoui, G. Roudaut, O. Chambin, A. Voilley, R. Saurel, Applications of spray-drying in microencapsulation of food ingredients: An overview, Food Research International, 40 (2007) 11071121.

[49] S. Graff, S. Hussain, J.C. Chaumeil, C. Charrueaul, Increased intestinal delivery of viable Saccharomyces boulardii by encapsulation in microspheres, Pharmaceutical Research, 25 (2008) 1290-1296.

[50] M. Saarela, I. Virkajarvi, H.L. Alakomi, T. Mattila-Sandholm, A. Vaari, T. Suomalainen, J. Matto, Influence of fermentation time, cryoprotectant and neutralization of cell concentrate on freezedrying survival, storage stability, and acid and bile exposure of Bifidobacterium animalis ssp lactis cells produced without milk-based ingredients, Journal of Applied Microbiology, 99 (2005) 1330 1339.

[51] A. Siaterlis, G. Deepika, D. Charalampopoulos, Effect of culture medium and cryoprotectants on the growth and survival of probiotic lactobacilli during freeze drying, Letters in Applied Microbiology, 48 (2009) 295-301.

[52] A. Faure, P. York, R.C. Rowe, Process control and scale-up of pharmaceutical wet granulation processes: a review, European Journal of Pharmaceutics and Biopharmaceutics, 52 (2001) 269-277. [53] M.T. Cook, G. Tzortzis, D. Charalampopoulos, V.V. Khutoryanskiy, Production and evaluation of dry alginate-chitosan microcapsules as an enteric delivery vehicle for probiotic bacteria, Biomacromolecules, 12 (2011) 2834-2840.

[54] M. Rinaudo, Main properties and current applications of some polysaccharides as biomaterials, Polymer International, 57 (2008) 397-430.

[55] B. Thu, P. Bruheim, T. Espevik, O. Smidsrod, P. SoonShiong, G. SkjakBraek, Alginate polycation microcapsules .1. Interaction between alginate and polycation, Biomaterials, 17 (1996) 1031-1040. 
[56] S.M.A. Wahab, M.A. Ahmed, F.A. Radwan, R.M. Hassan, A.M. ElRefae, Relative permittivity and electrical conductivity of some divalent metal alginate complexes, Materials Letters, 30 (1997) 183188.

[57] B.T. Stokke, K.I. Draget, O. Smidsrod, Y. Yuguchi, H. Urakawa, K. Kajiwara, Small-angle X-ray scattering and rheological characterization of alginate gels. 1. Ca-alginate gels, Macromolecules, 33 (2000) 1853-1863.

[58] O. Sandoval-Castilla, C. Lobato-Calleros, H.S. García-Galindo, J. Alvarez-Ramírez, E.J. VernonCarter, Textural properties of alginate-pectin beads and survivability of entrapped Lb. casei in simulated gastrointestinal conditions and in yoghurt, Food Research International, 43 (2010) 111117.

[59] T.Y. Sheu, R.T. Marshall, Microentrapment of Lactobacilli in calcium alginate gels, Journal of Food Science, 58 (1993) 557-561.

[60] D. Poncelet, R. Lencki, C. Beaulieu, J.P. Halle, R.J. Neufeld, A. Fournier, Production of alginate beads by emulsification internal gelation .1. Methodology, Applied Microbiology and Biotechnology, 38 (1992) 39-45.

[61] O. Smidsrod, G. Skjakbraek, Alginate as immobilization matrix for cells, Trends in Biotechnology, 8 (1990) 71-78.

[62] A. Martinsen, G. Skjakbraek, O. Smidsrod, Alginate as immobilization material .1. correlation between chemical and physical-properties of alginate gel beads, Biotechnology and Bioengineering, 33 (1989) 79-89.

[63] G. Skjakbraek, H. Grasdalen, O. Smidsrod, Inhomogeneous polysaccharide ionic gels, Carbohydr. Polym., 10 (1989) 31-54.

[64] I.T. Tai, A.M. Sun, Microencapsulation of recombinant cells - a new delivery system for genetherapy, Faseb Journal, 7 (1993) 1061-1069.

[65] M. Weber, A. Steinert, A. Jork, A. Dimmler, F. Thurmer, N. Schutze, C. Hendrich, U.

Zimmermann, Formation of cartilage matrix proteins by BMP-transfected murine mesenchymal stem cells encapsulated in a novel class of alginates, Biomaterials, 23 (2002) 2003-2013.

[66] B. Wright, R.A. Cave, J.P. Cook, V.V. Khutoryanskiy, S. Mi, B. Chen, M. Leyland, C.J. Connon, Enhanced viability of corneal epithelial cells for efficient transport/storage using a structurally modified calcium alginate hydrogel, Regenerative medicine, 7 (2012) 295-307.

[67] K.I. Draget, G.S. Braek, O. Smidsrod, Alginic acid gels - the effect of alginate chemicalcomposition and molecular-weight, Carbohydr. Polym., 25 (1994) 31-38.

[68] B. Albertini, B. Vitali, N. Passerini, F. Cruciani, M. Di Sabatino, L. Rodriguez, P. Brigidi, Development of microparticulate systems for intestinal delivery of Lactobacillus acidophilus and Bifidobacterium lactis, European Journal of Pharmaceutical Sciences, 40 (2010) 359-366.

[69] L. Sabikhi, R. Babu, D.K. Thompkinson, S. Kapila, Resistance of microencapsulated Lactobacillus acidophilus LA1 to processing treatments and simulated gut conditions, Food and Bioprocess Technology, 3 (2010) 586-593.

[70] L.T. Hansen, P.M. Allan-Wojtas, Y.L. Jin, A.T. Paulson, Survival of Ca-alginate microencapsulated Bifidobacterium spp. in milk and simulated gastrointestinal conditions, Food Microbiology, 19 (2002) 35-45.

[71] K. Sultana, G. Godward, N. Reynolds, R. Arumugaswamy, P. Peiris, K. Kailasapathy, Encapsulation of probiotic bacteria with alginate-starch and evaluation of survival in simulated gastrointestinal conditions and in yoghurt, Int. J. Food Microbiol., 62 (2000) 47-55.

[72] W.K. Ding, N.P. Shah, Effect of various encapsulating materials on the stability of probiotic bacteria, Journal of Food Science, 74 (2009) M100-M107.

[73] M. Papagianni, S. Anastasiadou, Encapsulation of Pediococcus acidilactici cells in corn and olive oil microcapsules emulsified by peptides and stabilized with xanthan in oil-in-water emulsions:

Studies on cell viability under gastro-intestinal simulating conditions, Enzyme and Microbial Technology, 45 (2009) 514-522. 
[74] P. Muthukumarasamy, P. Allan-Wojtas, R.A. Holley, Stability of Lactobacillus reuteri in different types of microcapsules, Journal of Food Science, 71 (2006) M20-M24.

[75] X.Y. Li, X.G. Chen, D.S. Cha, H.J. Park, C.S. Liu, Microencapsulation of a probiotic bacteria with alginate-gelatin and its properties, Journal of Microencapsulation, 26 (2009) 315-324.

[76] S.-J. Kim, S.Y. Cho, S.H. Kim, O.-J. Song, I.I.S. Shin, D.S. Cha, H.J. Park, Effect of microencapsulation on viability and other characteristics in Lactobacillus acidophilus ATCC 43121, LWT - Food Science and Technology, 41 (2008) 493-500.

[77] W. Krasaekoopt, B. Bhandari, H. Deeth, The influence of coating materials on some properties of alginate beads and survivability of microencapsulated probiotic bacteria, International Dairy Journal, 14 (2004) 737-743.

[78] G.K. Gbassi, T. Vandamme, S. Ennahar, E. Marchioni, Microencapsulation of Lactobacillus plantarum spp in an alginate matrix coated with whey proteins, Int. J. Food Microbiol., 129 (2009) 103-105.

[79] A.M. Liserre, M.I. Re, B. Franco, Microencapsulation of Bifidobacterium animalis subsp lactis in modified alginate-chitosan beads and evaluation of survival in simulated gastrointestinal conditions, Food Biotechnology, 21 (2007) 1-16.

[80] M. Kumar, A review of chitin and chitosan applications, Reactive \& Functional Polymers, 46 (2000) 1-27.

[81] R.K. Majeti N.V, A review of chitin and chitosan applications, Reactive and Functional Polymers, 46 (2000) 1-27.

[82] I.A. Sogias, V.V. Khutoryanskiy, A.C. Williams, Exploring the factors affecting the solubility of chitosan in water, Macromolecular Chemistry and Physics, 211 426-433.

[83] K.V.H. Prashanth, R.N. Tharanathan, Chitin/chitosan: modifications and their unlimited application potential - an overview, Trends in Food Science \& Technology, 18 (2007) 117-131.

[84] A.C.M. Wu, W.A. Bough, E.C. Conrad, K.E. Alden, Determination of molecular-weight distribution of chitosan by high-performance liquid-chromatography, Journal of Chromatography, 128 (1976) 8799.

[85] M. Rinaudo, Chitin and chitosan: Properties and applications, Progress in Polymer Science, 31 (2006) 603-632.

[86] J.Z. Lin, W.T. Yu, X.D. Liu, H.G. Xie, W. Wang, X.J. Ma, In vitro and in vivo characterization of alginate-chitosan-alginate artificial microcapsules for therapeutic oral delivery of live bacterial cells, Journal of Bioscience and Bioengineering, 105 (2008) 660-665.

[87] E.-S. Chan, S.-L. Wong, P.-P. Lee, J.-S. Lee, T.B. Ti, Z. Zhang, D. Poncelet, P. Ravindra, S.-H. Phan, Z.-H. Yim, Effects of starch filler on the physical properties of lyophilized calcium-alginate beads and the viability of encapsulated cells, Carbohydr. Polym., 83 225-232.

[88] F. Garcia-Ochoa, V.E. Santos, J.A. Casas, E. Gomez, Xanthan gum: production, recovery, and properties, Biotechnology Advances, 18 (2000) 549-579.

[89] L.D. McMaster, S.A. Kokott, S.J. Reid, V. Abratt, Use of traditional African fermented beverages as delivery vehicles for Bifidobacterium lactis DSM 10140, Int. J. Food Microbiol., 102 (2005) 231237.

[90] L.D. McMaster, S.A. Kokott, P. Slatter, Micro-encapsulation of Bifidobacterium lactis for incorporation into soft foods, World Journal of Microbiology \& Biotechnology, 21 (2005) 723-728.

[91] C. Desmond, R.P. Ross, E. O'Callaghan, G. Fitzgerald, C. Stanton, Improved survival of Lactobacillus paracasei NFBC 338 in spray-dried powders containing gum acacia, Journal of Applied Microbiology, 93 (2002) 1003-1011.

[92] Y. Dror, Y. Cohen, R. Yerushalmi-Rozen, Structure of gum arabic in aqueous solution, Journal of Polymer Science Part B-Polymer Physics, 44 (2006) 3265-3271.

[93] W.-C. Lian, H.-C. Hsiao, C.-C. Chou, Viability of microencapsulated bifidobacteria in simulated gastric juice and bile solution, Int. J. Food Microbiol., 86 (2003) 293-301. 
[94] A.D. Borza, N.T. Annan, D.L. Moreau, P.M. Allan-Wojtas, A. Ghanem, D. Rousseau, A.T. Paulson, L.T. Hansen, Microencapsulation in genipin cross-linked gelatine-maltodextrin improves survival of Bifidobacterium adolescentis during exposure to in vitro gastrointestinal conditions, Journal of Microencapsulation, 27 (2010) 387-399.

[95] F.L. Mi, Y.C. Tan, H.F. Liang, H.W. Sung, In vivo biocompatibility and degradability of a novel injectable-chitosan-based implant, Biomaterials, 23 (2002) 181-191.

[96] T. Heidebach, P. Forst, U. Kulozik, Transglutaminase-induced caseinate gelation for the microencapsulation of probiotic cells, International Dairy Journal, 19 (2009) 77-84.

[97] A. Picot, C. Lacroix, Encapsulation of bifidobacteria in whey protein-based microcapsules and survival in simulated gastrointestinal conditions and in yoghurt, International Dairy Journal, 14 (2004) 505-515.

[98] D. Ying, J. Sun, L. Sanguansri, R. Weerakkody, M.A. Augustin, Enhanced survival of spray-dried microencapsulated Lactobacillus rhamnosus GG in the presence of glucose, Journal of Food Engineering, 109 (2011) 597-602.

[99] S.B. Doherty, M.A. Auty, C. Stanton, R.P. Ross, G.F. Fitzgerald, A. Brodkorb, Survival of entrapped Lactobacillus rhamnosus GG in whey protein micro-beads during simulated ex vivo gastro-intestinal transit, International Dairy Journal, 22 (2012) 31-43.

[100] A. López-Rubio, E. Sanchez, S. Wilkanowicz, Y. Sanz, J.M. Lagaron, Electrospinning as a useful technique for the encapsulation of living bifidobacteria in food hydrocolloids, Food Hydrocolloids, 28 (2011) 159-167.

[101] C.L. Gerez, G. Font de Valdez, M.L. Gigante, C.R.F. Grosso, Whey protein coating bead improves the survival of the probiotic Lactobacillus rhamnosus CRL 1505 to low pH, Letters in Applied Microbiology, 54 (2012) 552-556.

[102] M. George, T.E. Abraham, Polyionic hydrocolloids for the intestinal delivery of protein drugs: Alginate and chitosan - a review, Journal of Controlled Release, 114 (2006) 1-14.

[103] R. Bibiloni, R.N. Fedorak, G.W. Tannock, K.L. Madsen, P. Gionchetti, M. Campieri, C. De Simone, R.B. Sartor, VSL\#3 probiotic-mixture induces remission in patients with active ulcerative colitis, Am J Gastroenterol, 100 (2005) 1539-1546.

[104] Y. Zhou, E. Martins, A. Groboillot, C.P. Champagne, P.C. Neufeld, Spectrophotometric quantification of lactic bacteria in alginate and control of cell release with chitosan coating, Journal of Applied Microbiology, 84 (1998) 342-348.

[105] J.F. Brandts, The thermodynamics of protein denaturation. I. The denaturation of chymotrypsinogen, Journal of the American Chemical Society, 86 (1964) 4291-4301.

[106] E. Lindh, Increased resistance of immunoglobulin a dimers to proteolytic degradation after binding of secretory component, The Journal of Immunology, 114 (1975) 284-286.

[107] S.B. Doherty, V.L. Gee, R.P. Ross, C. Stanton, G.F. Fitzgerald, A. Brodkorb, Development and characterisation of whey protein micro-beads as potential matrices for probiotic protection, Food Hydrocolloids, 25 (2011) 1604-1617.

[108] S.A. Hamad, S.D. Stoyanov, V.N. Paunov, Triggered cell release from shellac-cell composite microcapsules, Soft Matter, 8 (2012) 5069-5077.

[109] W. Sun, M.W. Griffiths, Survival of bifidobacteria in yogurt and simulated gastric juice following immobilization in gellanâ€"xanthan beads, Int. J. Food Microbiol., 61 (2000) 17-25.

[110] K.-Y. Lee, T.-R. Heo, Survival of Bifidobacterium longum immobilized in calcium alginate beads in simulated gastric juices and bile salt solution, Applied and Environmental Microbiology, 66 (2000) 869-873.

[111] C.I. And, K. Kailasapathy, Effect of co-encapsulation of probiotics with prebiotics on increasing the viability of encapsulated bacteria under in vitro acidic and bile salt conditions and in yogurt, Journal of Food Science, 70 (2005) M18-M23. 
[112] P. Marteau, M. Minekus, R. Havenaar, J.H. Huis in't Veld, Survival of lactic acid bacteria in a dynamic model of the stomach and small intestine: validation and the effects of bile, J Dairy Sci, 80 (1997) 1031-1037.

[113] P. Marteau, P. Pochart, Y. Bouhnik, S. Zidi, I. Goderel, J.C. Rambaud, Survival of Lactobacillusacidophilus and Bifidobacterium sp ingested in a fermented milk in the small-intestine - a rational basis for the use of probiotics in man, Gastroenterologie Clinique Et Biologique, 16 (1992) 25-28. [114] K. Molly, I. DeSmet, L. Nollet, M. VandeWoestyne, W. Verstraete, Effect of lactobacilli on the ecology of the gastro-intestinal microbiota cultured in the SHIME reactor, Microbial Ecology in Health and Disease, 9 (1996) 79-89.

[115] K. Molly, M. Vandewoestyne, I. Desmet, W. Verstraete, Validation of the simulator of the human intestinal microbial ecosystem (SHIME) reactor using microorganism-associated activities, Microbial Ecology in Health and Disease, 7 (1994) 191-200.

[116] P. De Boever, B. Deplancke, W. Verstraete, Fermentation by gut microbiota cultured in a simulator of the human intestinal microbial ecosystem Is improved by supplementing a soygerm powder, The Journal of Nutrition, 130 (2000) 2599-2606.

[117] T.T. Kararli, Comparison of the gastrointestinal anatomy, physiology, and biochemistry of humans and commonly used laboratory animals, Biopharm Drug Dispos, 16 (1995) 351-380.

[118] A.L. McCartney, Application of molecular biological methods for studying probiotics and the gut flora, Br J Nutr, 88 Suppl 1 (2002) S29-37.

[119] L. Mare, G.M. Wolfaardt, L.M. Dicks, Adhesion of Lactobacillus plantarum 423 and Lactobacillus salivarius 241 to the intestinal tract of piglets, as recorded with fluorescent in situ hybridization (FISH), and production of plantaricin 423 by cells colonized to the ileum, J Appl Microbiol, 100 (2006) 838-845.

[120] L. Masco, T. Vanhoutte, R. Temmerman, J. Swings, G. Huys, Evaluation of real-time PCR targeting the 16S rRNA and recA genes for the enumeration of bifidobacteria in probiotic products, Int J Food Microbiol, 113 (2007) 351-357.

[121] R. Kushal, S.K. Anand, H. Chander, In vivo demonstration of enhanced probiotic effect of coimmobilized Lactobacillus acidophilus and Bifidobacterium bifidum, International Journal of Dairy Technology, 59 (2006) 265-271.

[122] A. Lan, A. Bruneau, C. Philippe, V. Rochet, A. Rouault, C. Herve, N. Roland, S. Rabot, G. Jan, Survival and metabolic activity of selected strains of Propionibacterium freudenreichii in the gastrointestinal tract of human microbiota-associated rats, Br J Nutr, 97 (2007) 714-724.

[123] G. Tzortzis, A.K. Goulas, J.M. Gee, G.R. Gibson, A novel galactooligosaccharide mixture increases the bifidobacterial population numbers in a continuous in vitro fermentation system and in the proximal colonic contents of pigs in vivo, J Nutr, 135 (2005) 1726-1731.

[124] L.R. Fitzpatrick, J. Small, R.A. Hoerr, E.F. Bostwick, L. Maines, W.A. Koltun, In vitro and in vivo effects of the probiotic Escherichia coli strain M-17: immunomodulation and attenuation of murine colitis, Br J Nutr, 100 (2008) 530-541.

[125] J.L. Zani, F.W. da Cruz, A.F. dos Santos, C. Gil-Turnes, Effect of probiotic CenBiot on the control of diarrhoea and feed efficiency in pigs, J Appl Microbiol, 84 (1998) 68-71. 


\section{Captions for Figures}

Figure 1: The viability of two strains of Bifidobacteria (Bifidobacteria longum and Bifidobacterium breve) in simulated gastric juice ( $2 \% \mathrm{NaCl}$ adjusted to $\mathrm{pH} 2$ with $1 \mathrm{M} \mathrm{HCl}$, data not published). Cell enumeration was performed by plate counts on Wilkins-Chalgren anaerobe agar. Insert:

Bifidobacterium breve encapsulated in alginate microcapsules during exposure to simulated gastric juice, showing stages of cell lysis (0, 30, 60 min from left to right, scale: 5 micron). Bifidobacterium breve was dyed with pHrodo succinimidyl ester and examined by confocal microscopy. Note the appearance of damage to the cell membrane and eventual breakdown of cell.

Figure 2: Characteristics of the GI tract, showing the $\mathrm{pH}$ at the different parts.

Figure 3: 'Clumping' of microcapsules observed during air-drying, caused by aggregation of particles during the drying process. Microcapsules were produced by extrusion of a $2 \%$ alginate solution into calcium chloride solution followed by hardening and drying for $24 \mathrm{hrs}$ at room temperature. Particles were then imaged by scanning electron microscopy (SEM). Reprinted with permission from Biomacromolecules 2011, 12, 2834-2840 [47]. Copyright (2011) American Chemical Society

Figure 4: Fluid bed dried microcapsules, showing the granularity of the sample (left) and the large scale uniformity of the product (right). Microcapsules were produced as described in Figure 3, followed by drying using a fluid bed dryer (Retsch TG200, $15 \mathrm{~min}, 30^{\circ} \mathrm{C}$, air flow: $50 \%$ of full power, Idle flow: $183 \mathrm{~m}^{3} \mathrm{~h}^{-1}$ ).

Figure 5: Structural intricacies of alginate

Figure 6: Egg-box style divalent metal binding in alginate (a), a GG dimer showing binding space (b), alginate microcapsules (c) and a schematic diagram showing chain association by egg-box binding (d).

Figure7: Bacterial encapsulation in alginate by $A$ ) extrusion and $B$ ) emulsion

Figure 8: The chemical structure of chitosan

Figure 9: Effect of encapsulation in alginate, and alginate-chitosan microcapsules on the survival of Bifidobacterium breve in simulated gastric solution compared to free cells. The data show both wet and fluid bed dried microcapsules. Reprinted with permission from Biomacromolecules 2011, 12, 2834-2840 [47]. Copyright (2011) American Chemical Society

Figure 10: The structure of xanthan gum

Figure 11: Effect of various encapsulation matrices on the survival of $L$. rhamnosus in a $\mathrm{pH} 2$ solution. Graph constructed from data taken from Journal of Food Science 2009, 74, M100-M107 [1] with permission from John Wiley and Sons. Copyright (2009) John Wiley and Sons

Figure 12: Release of Bifidobacterium breve from alginate (red) and alginate-chitosan (blue) microcapsules during exposure to simulated gastric juice $(60 \mathrm{~min}$ ) followed by simulated intestinal juice (120 min). Measurements were taken using total cell counts on a light microscope in phase contrast mode. Reprinted with permission from Biomacromolecules 2011, 12, 2834-2840 [47]. Copyright (2011) American Chemical Society

Figure 13: Release of Lactobacillus rhamnosus from whey protein isolate microcapsules during exposure to (A) ex vivo gastric contents at pH 3.4 (filled circle), pH 2.4 (empty square) and pH 2.0 
(filled triangle) and (B) ex vivo intestinal contents at $\mathrm{pH} 6.6$ (filled rhombus). Reprinted with permission from International Dairy Journal 2012, 22, 31-43 [92]. Copyright (2011) Elsevier.

Figure 14: Schematic outline of the SHIME system, developed by De Boever et al [116]. The 5 vessels simulate the stomach, small intestine, ascending colon, transverse colon and the descending colon, in that order. permission of the author. 